\title{
Meta-analysis: implications of interleukin-28B polymorphisms in spontaneous and treatment- related clearance for patients with hepatitis $C$
}

María A Jiménez-Sousa ${ }^{*}{ }^{+}$, Amanda Fernández-Rodríguez ${ }^{\dagger}$, María Guzmán-Fulgencio, Mónica García-Álvarez and Salvador Resino*

\begin{abstract}
Background: Since 2009, several studies have identified single-nucleotide polymorphisms (SNPs) near the gene encoding for interleukin (IL)-28 (IL28B) that are strongly associated with spontaneous and treatment-induced hepatitis $\mathrm{C}$ virus (HCV) clearance. Because this large amount of data includes some inconsistencies, we consider assessment of the global estimate for each SNP to be essential.

Methods: Relevant studies assessing IL28B polymorphisms associated with sustained virologic response (SVR) and spontaneous clearance (SC) were identified from a literature search of PubMed up to 9 July, 2012. Studies were eligible studies if they included patients infected with HCV or HCV/HIV, or assessed any SNP located within or near the IL28B gene, SVR data available under standard treatment, and/or SC data in patients with acute HCV infection. Pooled odds ratios were estimated by fixed or random effects models when appropriate. Variables such as HCV genotype, ethnicity, and type of co-infection were studied.

Results: Of 282 screened studies, 67 were selected for SVR and 10 for SC. In total, 20,163 patients were studied for SVR and 3,554 for SC. For SVR, we found that all SNPs showed strong associations in patients with HCV genotypes 1 and 4, whereas the pooled ORs were almost three times lower for genotypes 2 and 3 (rs12979860 and rs8099917). Regarding ethnicity, the SNP most associated with SVR was rs 12979860 in white patients, whereas in East Asians it seemed to be rs8099917. The most studied SNP (rs12979860) showed similar results for patients coinfected with HCV/HIV, as for those infected with HCV only. Finally, rs12979860 and rs8099917 both appeared to be associated with SC.

Conclusions: $I L 28 B$ polymorphisms influence both the outcome of interferon treatment and the natural clearance of HCV. However we did not identify a universal predictor SNP, as the best genetic markers differed depending on patient ethnicity, genotype, and type of infection. Nevertheless, our results may be useful for more precise treatment decision-making.
\end{abstract}

Keywords: meta-analysis, systematic review, interleukin 28B, HCV, polymorphisms

\section{Background}

Currently, over 200 million people worldwide are chronically infected with hepatitis $\mathrm{C}$ virus (HCV) [1]. $\mathrm{HCV}$ is an important cause of acute and chronic hepatitis, with only $20 \%$ of patients have spontaneous clearance $(\mathrm{SC})$ of the virus. Unfortunately, around a quarter

\footnotetext{
*Correspondence: majimenezsousa@yahoo.es; sresino@isciii.es † Contributed equally

Unit of HIV/Hepatitis Coinfection, National Center for Microbiology, Health Institute Carlos III (ISCIII), 28220 Majadahonda, Madrid, Spain
}

of all patients will progress to develop cirrhosis. Other complications such as co-infection with HIV are common among patients infected with $\mathrm{HCV}$, because both viruses share the same routes of transmission [2].

To date, the mechanisms underlying $\mathrm{HCV}$ infection have not been completely defined. Over the past few decades, several host and viral factors have been found to be associated with differences in HCV clearance or persistence. However, an unexplained variability in treatment

\section{Ciomed Central}


outcome still exists, suggesting that the genetic background of the host plays an important role [1].

Nowadays, the standard of care for chronic HCV infection consists of pegylated interferon $-\alpha$ plus ribavirin (PEG-IFN/RBV). However, this treatment produces sustained virologic response (SVR) rates in only about 40 to $50 \%$ of patients with HCV genotype 1 and approximately $60 \%$ in those infected with genotype 4 , whereas over $80 \%$ of patients with genotypes 2 or 3 achieve SVR [2]. PEGIFN/RBV treatment is prolonged and costly, and is associated with dose-limiting side-effects, highlighting the need for accurate prediction of treatment failure.

Recently, three independent groups discovered several strongly correlated single genetic polymorphisms (SNPs) that, together with standard therapy, seem to play a role in clearing the virus [3-5]. These polymorphisms are located close to the interleukin $28 B$ (IL28B) gene on chromosome 19 . $I L 28 B$ encodes IFN $-\lambda 3$, which induces antiviral activity by itself and through the Janus kinase-signal transducer and activator of transcription (JAK-STAT) complex, which induces IFN-stimulated genes (ISGs) that also have antiviral activity against HCV [6]. Beyond their identification, little is known about the mechanisms involved between these genomic variants and viral clearance. However, it has been shown that unfavorable IL28B genetic variations are associated with higher pre-activated levels of ISGs, which could explain the poor response in these patients $[7,8]$.

Interest in this gene has led to a large number of publications showing IL28B polymorphisms as having an influence on HCV clearance. However, conflicting conclusions have been reached in some cases, with some studies reporting significant associations, and others reporting no such associations [9-11].

The aim of this study was to elucidate the pooled estimated effect of $I L 28 B$ polymorphisms on PEG-IFN/RBV treatment response and $\mathrm{SC}$, by conducting a meta-analysis of all eligible studies published up to 9 July 2012.

\section{Methods}

\section{Search strategy and selection criteria}

Relevant studies were identified by a literature search of PubMed without imposing study-period restrictions, using the following terms: 'hepatitis C', 'IL28B', 'SNP', 'spontaneous clearance', 'treatment', 'ribavirin' and 'interferon' (for the complete electronic search strategy, see Additional file 1). The information contained in this report is based on articles published before 9 July 2012 in any language. The meta-analysis was conducted following the guidelines published by Sutton et al. [12], and the data are reported in accordance with the Preferred Reporting Items for Systematic Reviews and Meta-Analyses (PRISMA) guidelines [13].
We developed strict inclusion and exclusion criteria before reviewing the studies and extracting the data in order to ensure maximum possible homogeneity between studies. Only articles satisfying the following criteria were further evaluated by two independent reviewers: 1) patients infected with $\mathrm{HCV}$ or $\mathrm{HCV} / \mathrm{HIV}$; 2) any SNP located within or near the IL28B gene; and 3) SVR data available for patients receiving standard treatment or d) SC data available for patients with acute HCV infections. Exclusion criteria were: 1) treatment duration of less than 24 weeks; 2) co-infection with HBV; 3) studies that included patients with organ transplantation; 4) studies with sample sizes of less than 40 subjects; 5) SVR data reported by methods other than PCR; 6) HCV genotypes other than 1, 2, 3 or 4.

To select the candidate studies, we carefully screened the title and abstract of each citation. When articles fulfilled the inclusion criteria, we examined the full text and extracted data from the study. When studies included several subgroups that did not all fulfill the inclusion criteria, we only incorporated into the meta-analysis those subgroups that did meet the inclusion criteria.

\section{Data extraction}

Two investigators independently assessed the selected papers and extracted all data. When data were unclear or required assumptions to be made, another investigator was consulted, so that a consensus could be reached before recording an entry in the database. When more than one paper studying the same cohort was found, only the study with the most extensive cohort was reviewed, excluding the remaining overlapping studies or data (for the extracted data from each study, see Additional file 2). When incongruent data were detected for one particular variable, they were discarded. We only included those data that could be confirmed by their appearance in different parts of the text (for instance in the main text and the tables).

When articles provided data from patients of different ethnicities, HCV genotypes, and/or types of infection ( $\mathrm{HCV}$ and $\mathrm{HCV} / \mathrm{HIV}$ ), these data were divided into subgroups, with each subgroup identified by a sequential letter. Regarding ethnicity, subjects were grouped into the main racial group of the study population based on their geographical origin or ancestry [14]. Studies with more than $99 \%$ of the study population described as Caucasian were considered to be Caucasian. For data presentation, genotypes 1 and 4 were considered to be in the same subgroup because of their similarity in response and the same applied for genotypes 2 and 3 [15].

To compare results between studies on fibrosis, we used 4 to 6 Ishak levels for the scale of fibrosis corresponding to a METAVIR score of 3 to 4 . HCV viral load data were collected at pre-treatment. 
Only patients who had an absence of detectable serum HCV RNA by PCR 24 weeks after treatment cessation were considered to have achieved SVR. For SC, patients with acute $\mathrm{HCV}$ infection who had undetectable levels HCV RNA on repeated examination without prior IFN therapy were considered to have spontaneously resolved the infection.

In an attempt to include the majority of studies and to complete any missing data, we contacted some authors of individual studies.

\section{Quality appraisal}

To evaluate the quality of the included studies, two investigators appraised them independently using a checklist based on the Graphic Appraisal Tool for Epidemiological studies (GATE) [16]. Each item was rated as +1 (well reported and reliable), 0 (unclear, insufficient detail provided) or -1 (poorly reported, not useful or reliable). The overall validity of each study was also rated by a similar system: +1 (most of the quality items were fulfilled), 0 (some criteria were not fulfilled), or -1 (few or none of the items were fulfilled).

\section{Statistical analysis}

We calculated whether all studied SNPs in the present meta-analysis concurred with Hardy-Weinberg equilibrium (HWE) [17] using the $\chi^{2}$ test, with equilibrium considered at $P>0.05$.

Overall, meta-analyses were performed only when two or more papers studying the same SNP were available. In all analyses, pooled odds ratios (ORs) and $95 \%$ confidence intervals (CIs) were calculated (favorable homozygous versus heterozygous plus unfavorable homozygous). The significance of the pooled OR was calculated by the $Z$-test, and was considered significant at $P<0.05$. A fixed effect model (the traditional Mantel-Haenszel test) was used for homogeneous studies [18]. The heterogeneity of each group of ORs was assessed by the $\chi^{2}$ test, which suggests the presence of heterogeneity when $P<0.1$. Heterogeneity was quantified with the $I^{2}$ metric, which provides a measure of the degree of inconsistency in the studies' results $\left(I^{2}>50 \%\right.$ indicated considerable heterogeneity). When significant heterogeneity existed, a random-effects model (the DerSimonian and Laird method [19]), was used, and a subgroup meta-analysis and forest plot based on ethnicity, $\mathrm{HCV}$ genotype, and co-infection data ( $\mathrm{HCV}$ or $\mathrm{HCV} / \mathrm{HIV})$ were performed to identify the effect modifiers [20]. Moreover, the Galbraith plot was used to detect possible outliers of the heterogeneity, which could have biased the combined estimate. This graphical method allowed those studies that had a strong influence on the pooled results to be checked $[21,22]$. Trials outside the Galbraith limits were trials where the $95 \%$ CI did not contain the pooled estimate.
In addition, when heterogeneity was detected, metaregression analysis was also performed, with the aim of defining the potential effect of the covariates on spontaneous or treatment-related clearance. The regression coefficient obtained describes how SC or SVR changes with each unit increase in the covariate. Significance of the linearity relationship between SC or SVR and the covariate was identified by the $P$-value; the adjusted $R^{2}$ term indicates the proportion of between-study variance explained by the included variable. The evaluated variables were as follows: genotype ( $1 / 4$ versus $2 / 3$ ), ethnicity (Caucasian versus other, and Caucasian versus East Asian), type of viral infection (HCV mono-infection versus $\mathrm{HCV} / \mathrm{HIV}$ coinfection), viral load (HCV RNA $<6 \log _{10}$ versus HCV RNA $\geq 6 \log _{10}$ ), advanced fibrosis F3/F4 ( $\leq 30 \%$ versus $>$ $30 \%$ ), and prior $\mathrm{HCV}$ treatment (naive versus previous $\mathrm{HCV}$ treatment failures).

Publication bias was assessed by funnel plot and the Egger linear regression test $[23,24]$, which detects funnel plot asymmetry. When the Egger test reported a $P<0.05$, publication bias was assumed to exist.

Sensitivity analyses [24] were also conducted to assess the consistency of results and to investigate the influence of one study on the overall meta-analysis. It was carried out by sequential omission of individual studies.

All analyses were performed using Stata software (version 11.0; Stata Corporation, College Station, TX, USA).

\section{Results}

\section{Studies and data included in the meta-analysis}

The literature search identified 282 publications (Figure 1). After initial screening and removal of duplicates $(n=1)$, 207 articles were rejected based on the title/abstract $(n=$ 82 ) or the full text $(\mathrm{n}=125)$, because they did not meet the inclusion criteria. This left 74 studies that were eligible for inclusion (see Additional file 2), comprising 67 that were selected for SVR meta-analysis [5,9-11,25-87] and 10 for SC meta-analysis [26,28,65,88-94].; 3 of these studies were included in both analyses $[26,28,65]$. Regarding the quality appraisal of the included studies for SVR, 21 were rated as $+1,43$ as 0 , and two as -1 (see Additional file 3), and for SC, four studies were rated as +1 and six as 0 (see Additional file 4).

To date, 21 polymorphisms within or near IL28B have been investigated in relation to SVR (rs688187, rs4803 219, rs4803221, rs4803223, rs4803224, rs7248668, rs724 8931, rs8099917, rs8103142, rs8105790, rs8109886, rs10 853727, rs10853728, rs11881222, rs12972991, rs1297 9860, rs12980275, rs12980602, rs12982533, rs28416813, rs35790907). Those polymorphisms genotyped only in one study had to be discarded from the meta-analysis because of the impossibility of performing statistical analysis. This was the case for two SNPs from Chen $e t$ al. (2011) [37] (rs28416813 and rs4803219); and ten 


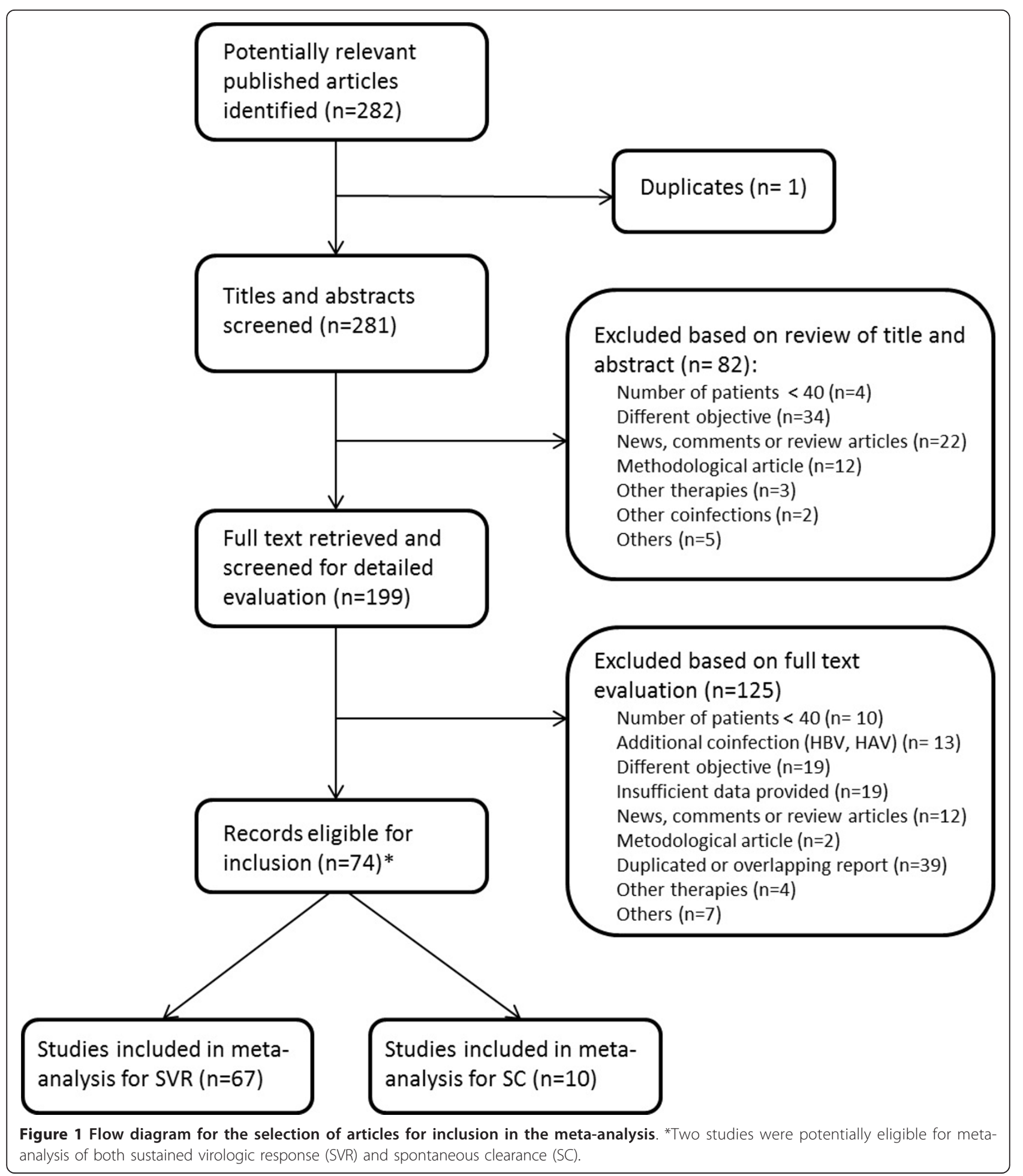

from Smith et al. (2011) [52] (rs12980602, rs12982533, rs35790907, rs4803221, rs4803224, rs688187, rs7248931, rs8109886, rs12972991, and rs10853727). With respect to SC, one SNP from Renda et al. (2011) [90] (rs8103142) and five from Rao et al. (rs10853728, rs11881222, rs4803219, rs4803223, rs8105790) were excluded. In summary, eight polymorphisms were analyzed in the present study (see Additional file 5). All of the studied SNPs fulfilled the HWE, except for rs12979860, rs11881222, rs8103142, and rs10853728. 
The most studied IL28B SNPs and their favorable genotypes for SVR were: rs12979860 (CC), rs8099917 (TT), and rs12980275 (AA). The rs12979860 polymorphism was assessed in 12,184 patients from 42 studies; rs8099917 was assessed in 11,839 patients from 39 studies; and rs12980275 was assessed in 2,786 patients from 6 studies. For the SC analysis, 2,340 patients from 7 studies and 1,783 patients from 4 studies were analyzed for rs12979860 and rs8099917, respectively.

\section{Baseline characteristics}

The publication year of the studies ranged from 2009 to 2012 (see Additional file 2 for a summary of the baseline characteristics of the included publications for SVR ( $\mathrm{n}=$ $67)$ and SC ( $n=10)$, respectively). The studies were mostly conducted with Caucasian and Asian populations. Nearly $50 \%$ of the studies included only patients with genotype 1 , whereas patients with genotype 4 were infrequently studied. As regards the type of infection, most of the articles studied patients infected with HCV only, whereas patients co-infected with HCV/HIV were assessed for SVR in only seven articles and for SC in only one article, which was mixed.

When articles were divided into subgroups, each one was identified by a sequential letter (see Additional file 6).

\section{Publication bias test results}

Following recommendations for correct funnel-plot interpretation, SNPs found in less than 10 articles should not be evaluated for publication bias [95], thus, publication bias was only analyzed for rs12979860 and rs8099917 for SVR. Funnel-plot results (Figure 2) and Egger test results (see Additional file 7) showed that there was statistical significance in publication bias only for $\operatorname{rs} 8099917$ ( $P=$ 0.005) in the SVR meta-analysis.

\section{Overall and subgroup meta-analysis}

We performed two overall meta-analyses separately for SVR and SC, with all data grouped by polymorphism. When heterogeneity was identified, we stratified the data into subgroups according to ethnicity (African, African American, Asian, Caucasian, Hispanic, and North African), HCV genotype $(1 / 4,2 / 3$, and mix) and type of viral infection (HCV or HCV/HIV) (Table 1$)$. In parallel, we performed meta-regression analysis to investigate the possible influence of several variables on the heterogeneity. Genotype and allele frequencies from all analyzed IL28B SNPs were also stratified by ethnicity (see Additional file 8).

\section{Sustained virologic response}

Sensitivity analysis was carried out using sequential omission of individual studies to investigate the influence of each individual study on the overall meta-analysis (Figure 3). rs12979860 In total, 42 studies reported data for rs12979860 (Table 1; see Additional file 9). The pooled OR for overall data was 3.77 (95\% CI $=3.25$ to 4.37 ) and there was heterogeneity $\left(P<0.001 ; I^{2}=52.3 \%\right)$. When the Galbraith plot was analyzed, two outliers of heterogeneity were identified (Moghaddam et al. [11] and Thompson et al. [25]) (Figure 4). A forest plot omitting the mentioned outlier studies was constructed, which reduced heterogeneity $\left(I^{2}=47.54 \%\right)$, but the significance of the OR was not altered $(P<0.001$; OR $=$ 3.78 ; $95 \% \mathrm{CI}=3.36$ to 4.24$)$. In addition, sensitivity analysis showed that none of the 42 studies should be omitted from subsequent statistical analysis. Based on these results and population characteristics, we did not find enough reasons to discard the papers of Moghaddam et al. [11] and Thompson et al. [25] from subsequent analysis.

When forest plots were constructed based on ethnicity, $\mathrm{HCV}$ genotype, and type of viral infection, we obtained the following data:

- Ethnicity: Africans (OR $=3.75 ; 95 \% \mathrm{CI}=1.60$ to 8.79), African Americans (OR $=3.19 ; ; 95 \% \mathrm{CI}=0.99$ to $10.29)$, Asians $(\mathrm{OR}=3.27$; $95 \% \mathrm{CI}=2.21$ to 4.84$)$, Caucasians $(\mathrm{OR}=3.63 ; 95 \% \mathrm{CI}=4.01$ to 4.37$)$, Hispanics $(\mathrm{OR}=7.17 ; 95 \% \mathrm{CI}=0.56$ to 92.34$)$, North Africans $(\mathrm{OR}=1.67 ; 95 \% \mathrm{CI}=0.52$ to 5.38$)$, and mixed $(\mathrm{OR}=$ 3.95 ; $95 \% \mathrm{CI}=2.68$ to 5.83 ) (see Additional file 10 ). Note that the subgroup results for Africans $(n=1)$ [62], African Americans $(\mathrm{n}=2)[25,59]$, Hispanics $(\mathrm{n}=2)$ $[9,25]$, and North Africans $(n=1)$ [78] are based on analysis of a very small number of studies, therefore there is uncertainty associated with the estimates reported.

- $\mathrm{HCV}$ genotype: genotype $1 / 4(\mathrm{OR}=4.20 ; 95 \% \mathrm{CI}=$ 3.61 to 4.90$)$, genotype $2 / 3(\mathrm{OR}=1.59 ; 95 \% \mathrm{CI}=1.14$ to 2.21$)$, and mixed $(\mathrm{OR}=3.97 ; 95 \% \mathrm{CI}=3.30$ to 4.77 ) (see Additional file 11). The difference between genotypes $1 / 4$ and $2 / 3$ was significant.

Data for OR (95\% CI) were separated by both HCV genotype and ethnicity simultaneously (see Additional file 12). These data can only provide limited insight, because very few articles presented data independently for both variables.

- Type of viral infection: HCV mono-infected $(\mathrm{OR}=$ $3.55 ; 95 \% \mathrm{CI}=3.04$ to 4.14 ) and $\mathrm{HCV} / \mathrm{HIV}$ co-infected $(\mathrm{OR}=4.07 ; 95 \% \mathrm{CI}=2.66$ to 6.21$)$ (see Additional file 13).

Subgroup analysis showed that HCV genotype was the only significant cause of heterogeneity between all the studied variables, as the overall analysis was heterogeneous, whereas the subgroup analysis was homogeneous. These data were confirmed by meta-regression, where only the variance between studies attributable to $\mathrm{HCV}$ genotype was significant (adjusted $R^{2}=83.61 \% ; P<0.001$ ). 


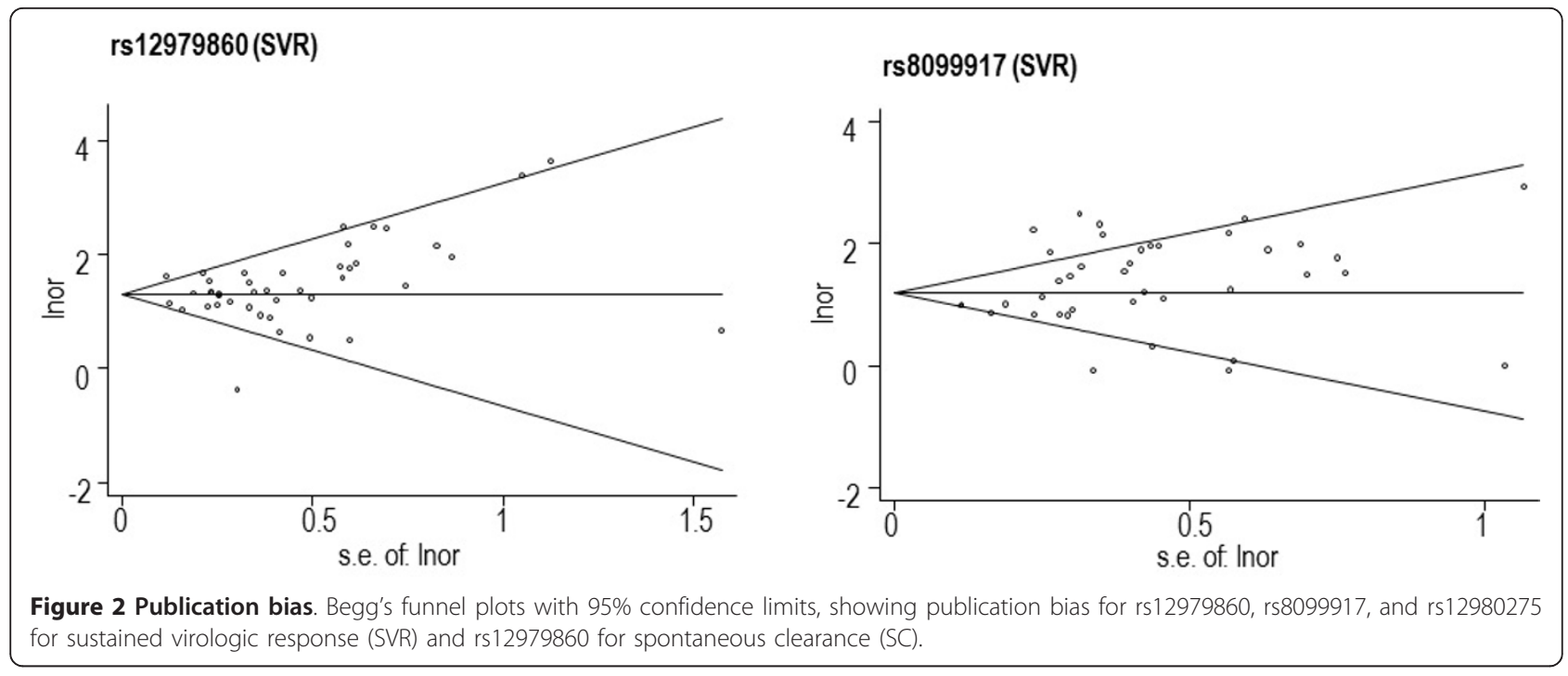

rs8099917 There were 39 eligible studies reporting data on rs8099917 (Table 1, see Additional file 14). The pooled OR for overall data was $3.86(95 \% \mathrm{CI}=3.18$ to 4.69$)$ and the overall heterogeneity was also significant $(P<0.001$; $\left.I^{2}=71.9 \%\right)$. When the Galbraith plot was constructed (Figure 4), six outliers of the heterogeneity were identified: five studies grouped together (all Asians with genotype 1 and most Japanese patients) and one study (Moghaddam et al. [11]), which was also an outlier for the rs12979860 analysis. By excluding these six studies from the analysis, similar pooled OR and significance was obtained $(\mathrm{OR}=$ 3.28; $95 \% \mathrm{CI}=2.81$ to $3.83 ; P<0.001)$ and heterogeneity was still detected $\left(I^{2}=56.23 \%\right)$. Likewise, sensitivity analysis showed that none of the 39 studies should be omitted from subsequent statistical analysis.

When forest plots were performed based on ethnicity, $\mathrm{HCV}$ genotype, and type of viral infection, we obtained the following data:

- Ethnicity: Africans $(\mathrm{OR}=2.02 ; 95 \% \mathrm{CI}=0.88$ to 4.65$)$, Asians $(\mathrm{OR}=4.82 ; 95 \% \mathrm{CI}=3.80$ to 6.11$)$, Caucasians $(\mathrm{OR}=2.71 ; 95 \% \mathrm{CI}=2.07$ to 3.54$)$, Hispanics $(\mathrm{OR}=$ $11.25 ; 95 \% \mathrm{CI}=3.51$ to 36.00$)$, and mixed $(\mathrm{OR}=2.27$; $95 \% \mathrm{CI}=1.52$ to 3.38 ). There was only one publication dealing with a Hispanic population [9], therefore the result relates entirely to this study (Additional file 15). With regard to the Asian and Caucasian subgroups, there was still heterogeneity ( $I^{2}=60.3 \%$ and 50.8 respectively), which could be due to the mixture of $\mathrm{HCV}$ genotypes within each group.

- $\mathrm{HCV}$ genotype: genotype $1 / 4(\mathrm{OR}=4.55 ; 95 \% \mathrm{CI}=$ 3.76 to 5.52$)$, genotype $2 / 3(\mathrm{OR}=1.59 ; 95 \% \mathrm{CI}=1.22$ to $2.08)$, and mixed ( $\mathrm{OR}=3.43 ; 95 \% \mathrm{CI}=2.36$ to 5.00$)$ (see Additional file 16). Again, as was shown for rs12979860, the difference between genotype $1 / 4$ and $2 / 3$ was significant.
- Type of viral infection: HCV mono-infected $(\mathrm{OR}=$ $3.78 ; 95 \% \mathrm{CI}=3.14$ to 4.57$), \mathrm{HCV} / \mathrm{HIV}$ co-infected (OR $=$ $3.70 ; 95 \% \mathrm{CI}=0.96$ to 14.31 ), and mixed (pooled patients with HCV mono-infection, and patients with HCV/HIV co-infection; $\mathrm{OR}=2.07 ; 95 \% \mathrm{CI}=1.10$ to 3.92 ). It must be taken into account that heterogeneity within the monoinfected subgroup was still high $\left(I^{2}=65.3 \%\right)$. Regarding $\mathrm{HCV} / \mathrm{HIV}$ co-infected and mixed subgroups, only a few studies were included ( $\mathrm{n}=3$ and $\mathrm{n}=1$, respectively), therefore care needs to be taken with the estimates reported (see Additional file 17).

Meta-regression analysis indicated the proportion of significant variance accounting for each different covariate: ethnicity (Caucasians versus Asians: adjusted $R^{2}=26.00 \%$; $P=0.002$ ), $\mathrm{HCV}$ genotype (adjusted $\mathrm{R}^{2}=51.57 \% ; P<$ 0.001 ), and advanced fibrosis (adjusted $R^{2}=32.64 \% ; P=$ 0.016). Type of infection and baseline HCV viral load did not seem to influence the heterogeneity $(P=0.992$ and $P=0.087$ respectively).

rs12980275 The pooled OR for overall data was 3.95; $95 \% \mathrm{CI}=2.39$ to 6.53$)$ and the heterogeneity was significant $\left(P<0.001 ; \mathrm{I}^{2}=77.7 \%\right)$ (Table 1, Additional file 18). Galbraith plot identified Tanaka et al. [5] as an outlier of the heterogeneity (data not shown); however, the low number of studies prevented us from drawing firm conclusions about this analysis.

Subgroup analysis was performed based on ethnicity, $\mathrm{HCV}$ genotype, and type of infection. We obtained the following data:

- Ethnicity: Asians (OR $=5.00 ; 95 \% \mathrm{CI}=1.65$ to 15.11), Caucasians ( $\mathrm{OR}=3.44 ; 95 \% \mathrm{CI}=1.38$ to 8.57$)$, Hispanics (OR $=8.84 ; 95 \% \mathrm{CI}=2.76$ to 28.34$)$, and mixed $(\mathrm{OR}=1.46 ; 95 \% \mathrm{CI}=0.50$ to 4.24$)$. However, it has to be noted that only two studies were available for the Asian $(n=2[5,37])$ subgroup and only one each for 
Table 1 Summary of Forest plots showing the associations between IL28B polymorphisms and SVR or SC.

\begin{tabular}{|c|c|c|c|c|c|c|c|c|c|}
\hline Stratification & Subgroup & No. $^{a}$ & OR $(95 \% \mathrm{CI})^{\mathrm{b}}$ & $P$ value & $\begin{array}{l}\text { SVR/favorable } \\
\text { genotype }^{c}\end{array}$ & $\begin{array}{l}\text { SVR/unfavorable } \\
\text { genotype }^{d}\end{array}$ & Weight, ${ }^{\mathrm{e}}$ & $1^{2}, \%^{f}$ & $P$-value ${ }^{g}$ \\
\hline \multicolumn{10}{|l|}{ rs12979860 } \\
\hline Overall & & 42 & 3.77 (3.25 to 4.37$)$ & $<0.001$ & $3,516 / 4,951$ & $2,775 / 7,233$ & 100 & 52.3 & $<0.001$ \\
\hline \multirow[t]{8}{*}{ By ethnicity } & A & 1 & 3.75 (1.60 to 8.79 ) & 0.002 & $18 / 30$ & $28 / 98$ & 1.75 & NA & NA \\
\hline & $\mathrm{AA}$ & 2 & $\begin{array}{l}3.19(0.99 \text { to } \\
10.29)\end{array}$ & 0.052 & $26 / 59$ & $76 / 414$ & 3.50 & 71.1 & 0.063 \\
\hline & As & 7 & 3.27 (2.21 to 4.84$)$ & $<0.001$ & $1,137 / 1,565$ & $136 / 315$ & 12.35 & 40.4 & 0.122 \\
\hline & C & 37 & 3.63 (4.01 to 4.37 ) & $<0.001$ & $2,021 / 2,846$ & $2,168 / 5,392$ & 64.92 & 56.5 & $<0.001$ \\
\hline & $\mathrm{H}$ & 2 & $\begin{array}{l}7.17 \text { (0.56 to } \\
92.34)\end{array}$ & 0.131 & $38 / 54$ & $59 / 161$ & 2.29 & 81.5 & 0.020 \\
\hline & NA & 1 & 1.67 (0.52 to 5.38) & 0.393 & $10 / 16$ & $22 / 44$ & 1.14 & NA & NA \\
\hline & Mixed & 13 & 3.95 (2.68 to 5.83 ) & $<0.001$ & $266 / 381$ & 286/806 & 14.35 & 30.1 & 0.143 \\
\hline & Overall & 63 & 3.59 (3.10 to 4.15$)$ & $<0.001$ & $3,516 / 4,951$ & $2,775 / 7,230$ & 100 & 48.5 & $<0.001$ \\
\hline \multirow{4}{*}{$\begin{array}{l}\text { By HCV } \\
\text { genotype }\end{array}$} & $1 / 4$ & 37 & 4.20 (3.61 to 4.90$)$ & $<0.001$ & $1,728 / 2,647$ & $1,641 / 5,106$ & 59.33 & 27.5 & 0.065 \\
\hline & $2 / 3$ & 15 & 1.59 (1.14 to 2.21$)$ & 0.006 & $640 / 779$ & $537 / 719$ & 16.59 & 19.8 & 0.232 \\
\hline & Mixed & 11 & 3.97 (3.30 to 4.77 ) & $<0.001$ & $1,130 / 1,506$ & $577 / 1,386$ & 24.07 & 0.0 & 0.581 \\
\hline & Overall & 63 & 3.58 (3.10 to 4.15 ) & $<0.001$ & $3,498 / 4,932$ & $2,755 / 7,211$ & 100 & 48.3 & $<0.001$ \\
\hline \multirow[t]{3}{*}{$\begin{array}{l}\text { By type of } \\
\text { infection }\end{array}$} & $\mathrm{HCV}$ & 57 & 3.55 (3.04 to 4.14$)$ & $<0.001$ & $3,390 / 4,765$ & $2,684 / 6,949$ & 92.53 & 51.3 & $<0.001$ \\
\hline & $\mathrm{HCV} / \mathrm{HIV}$ & 6 & 4.07 (2.66 to 6.21) & $<0.001$ & $126 / 186$ & $91 / 284$ & 7.47 & 0.0 & 0.436 \\
\hline & Overall & 63 & 3.59 (3.10 to 4.15$)$ & $<0.001$ & $3,516 / 4,951$ & $2775 / 7233$ & 100 & 48.4 & $<0.001$ \\
\hline \multicolumn{10}{|l|}{ rs8099917 } \\
\hline Overall & & 39 & 3.86 (3.18 to 4.69) & $<0.001$ & $5,222 / 8,106$ & $1,298 / 3,733$ & 100 & 71.9 & $<0.001$ \\
\hline \multirow[t]{6}{*}{ By ethnicity } & A & 1 & 2.02 (0.88 to 4.65$)$ & 0.097 & $37 / 90$ & $10 / 39$ & 1.98 & NA & NA \\
\hline & As & 30 & $4.82(3.80$ to 6.11$)$ & $<0.001$ & $3,548 / 5,535$ & $477 / 1740$ & 53.23 & 60.3 & $<0.001$ \\
\hline & C & 20 & 2.71 (2.07 to 3.54$)$ & $<0.001$ & $1,314 / 1,982$ & $624 / 1491$ & 33.68 & 50.8 & 0.005 \\
\hline & $\mathrm{H}$ & 1 & $\begin{array}{l}11.25 \text { (3.51 to } \\
36.00)\end{array}$ & $<0.001$ & $25 / 29$ & $25 / 70$ & 1.40 & NA & NA \\
\hline & Mixed & 5 & 2.27 (1.52 to 3.38 ) & $<0.001$ & $298 / 468$ & $162 / 392$ & 9.71 & 34.4 & 0.192 \\
\hline & Overall & 57 & 3.63 (3.04 to 4.34) & $<0.001$ & $5,222 / 8,104$ & $1,298 / 3,732$ & 100 & 64.0 & $<0.001$ \\
\hline \multirow{4}{*}{$\begin{array}{l}\text { By HCV } \\
\text { genotype }\end{array}$} & $1 / 4$ & 37 & 4.55 (3.76 to 5.52 ) & $<0.001$ & $3,157 / 5,473$ & $815 / 2971$ & 71.23 & 60.5 & $<0.001$ \\
\hline & $2 / 3$ & 16 & 1.59 (1.22 to 2.08$)$ & 0.001 & $1,362 / 1,706$ & $405 / 567$ & 21.20 & 10.1 & 0.338 \\
\hline & Mixed & 4 & $3.43(2.36$ to 5.00$)$ & $<0.001$ & $643 / 850$ & $65 / 162$ & 7.57 & 0.0 & 0.733 \\
\hline & Overall & 57 & 3.59 (3.00 to 4.29$)$ & $<0.001$ & $5,162 / 8,029$ & $1,285 / 3,700$ & 100 & 64.1 & $<0.001$ \\
\hline \multirow{4}{*}{$\begin{array}{l}\text { By type of } \\
\text { infection }\end{array}$} & $\mathrm{HCV}$ & 50 & 3.78 (3.14 to 4.57$)$ & $<0.001$ & $4,948 / 7,681$ & $1,179 / 3,443$ & 90.07 & 65.3 & $<0.001$ \\
\hline & HCV/HIV & 3 & $\begin{array}{l}3.70 \text { (0.96 to } \\
14.31)\end{array}$ & 0.058 & $56 / 104$ & $11 / 56$ & 3.04 & 58.8 & 0.088 \\
\hline & Mix & 4 & 2.07 (1.10 to 3.92 ) & 0.025 & $218 / 321$ & $108 / 234$ & 6.89 & 50.3 & 0.110 \\
\hline & Overall & 57 & 3.63 (3.03 to 4.33 ) & $<0.001$ & $5,222 / 8,106$ & $1,298 / 3,733$ & 100 & 64.0 & $<0.001$ \\
\hline \multicolumn{10}{|l|}{ rs12980275 } \\
\hline Overall & & 6 & 3.95 (2.39 to 6.53$)$ & $<0.001$ & $1,047 / 1,433$ & $575 / 1,353$ & 100 & 77.7 & $<0.001$ \\
\hline \multirow[t]{3}{*}{ By ethnicity } & As & 2 & $\begin{array}{l}5.00(1.65 \text { to } \\
15.11)\end{array}$ & 0.004 & $633 / 836$ & $66 / 206$ & 34.60 & 88.9 & 0.003 \\
\hline & C & 4 & 3.44 (1.38 to 8.57$)$ & 0.008 & $374 / 543$ & $465 / 1,045$ & 43.85 & 67.2 & 0.027 \\
\hline & $\mathrm{H}$ & 1 & $\begin{array}{l}8.84(2.76 \text { to } \\
28.34)\end{array}$ & $<0.001$ & $22 / 26$ & $28 / 73$ & 10.30 & NA & NA \\
\hline
\end{tabular}


Table 1 Summary of Forest plots showing the associations between IL28B polymorphisms and SVR or SC. (Continued)

\begin{tabular}{|c|c|c|c|c|c|c|c|c|c|}
\hline & Mix & 1 & $1.46(0.50$ to 4.24$)$ & 0.484 & $18 / 28$ & $16 / 29$ & 11.24 & NA & NA \\
\hline & Overall & 8 & 3.91 (2.31 to 6.62) & $<0.001$ & $1,047 / 1,433$ & $575 / 1,353$ & 100 & 75.7 & $<0.001$ \\
\hline \multirow[t]{5}{*}{$\begin{array}{l}\text { By HCV } \\
\text { genotype }\end{array}$} & $1 / 4$ & 4 & $\begin{array}{l}6.33 \text { (2.64 to } \\
15.16)\end{array}$ & $<0.001$ & $457 / 694$ & $428 / 1,148$ & 59.27 & 87.4 & $<0.001$ \\
\hline & $2 / 3$ & 2 & 1.78 (0.38 to 8.25) & 0.460 & $58 / 62$ & $86 / 97$ & 11.79 & 27.3 & 0.241 \\
\hline & Mix & 2 & 2.44 (1.38 to 4.32$)$ & 0.002 & $532 / 677$ & $61 / 108$ & 28.93 & 22.5 & 0.256 \\
\hline & Overall & 8 & 3.91 (2.31 to 6.62) & $<0.001$ & $1,047 / 1,433$ & $575 / 1,353$ & 100 & 75.7 & $<0.001$ \\
\hline & Subgroup & No. $^{a}$ & OR $[95 \% \mathrm{Cl}]^{\mathrm{b}}$ & $P$ value & $\begin{array}{l}\text { SC/favorable } \\
\text { genotype }^{c}\end{array}$ & $\begin{array}{l}\text { SC/unfavorable } \\
\text { genotype }^{d}\end{array}$ & Weight, \% ${ }^{\mathrm{e}}$ & $\mathrm{I}^{2}, \%^{f}$ & $P$-value ${ }^{g}$ \\
\hline \multicolumn{10}{|l|}{ rs12979860 } \\
\hline Overall & & 7 & 3.20 (2.03 to 5.05) & $<0.001$ & $496 / 1,091$ & $248 / 1230$ & 100 & 81.8 & $<0.001$ \\
\hline \multirow[t]{3}{*}{ By ethnicity } & As & 1 & 1.31 (0.79 to 2.15) & 0.291 & $43 / 180$ & $37 / 191$ & 14.70 & $\mathrm{NA}$ & NA \\
\hline & $C$ & 6 & 3.78 (2.60 to 5.50$)$ & $<0.001$ & 453/911 & $211 / 1,039$ & 85.30 & 67.9 & 0.008 \\
\hline & Overall & 7 & 3.20 (2.03 to 5.05$)$ & $<0.001$ & $496 / 1,091$ & $248 / 1,230$ & 100 & 81.8 & $<0.001$ \\
\hline \multirow[t]{4}{*}{$\begin{array}{l}\text { By HCV } \\
\text { genotype }\end{array}$} & 1 & 2 & 5.66 (3.28 to 9.77 ) & $<0.001$ & $253 / 410$ & $108 / 522$ & 30.91 & 70.3 & 0.067 \\
\hline & Mix & 4 & 2.34 (1.48 to 3.69 ) & $<0.001$ & $183 / 528$ & $113 / 557$ & 54.73 & 59.8 & 0.058 \\
\hline & Unknown & 1 & 2.96 (1.75 to 5.02 ) & $<0.001$ & $60 / 153$ & 27/151 & 14.37 & NA & NA \\
\hline & Overall & 7 & 3.20 (2.03 to 5.05$)$ & $<0.001$ & 496/1,091 & $248 / 1,230$ & 100 & 81.8 & $<0.001$ \\
\hline \multicolumn{10}{|l|}{ rs8099917 } \\
\hline Overall & & 4 & $3.60(2.70$ to 4.81$)$ & $<0.001$ & $340 / 1,149$ & $72 / 634$ & 100 & 46.6 & 0.132 \\
\hline
\end{tabular}

Abbreviations: A, African; AA, African American; As, Asian; C, Caucasian; H, Hispanic; NA, North African; ND, no data; RCT, randomized controlled trial; SC, spontaneous clearance; SVR, sustained virologic response.

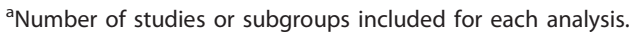

${ }^{b}$ Pooled odds ratios were calculated by fixed or random effects models when appropriate. The significance of the pooled OR was calculated by the $Z$-test, and was considered significant at $P<0.05$.

${ }^{\mathrm{C}}$ Number of patients with favorable genotype that achieved SVR or SC with respect to the total number of patients showing favorable genotype.

${ }^{d}$ SVR or SC/unfavorable genotype state for the number of patients with unfavorable genotype that achieved SVR or SC with respect to the total number of patients showing unfavorable genotype.

e Relative weight of each study's contribution to the analysis.

${ }^{f}$ Represents the proportion of heterogeneity.

${ }^{g} p<0.1$ suggests presence of heterogeneity.

the Hispanic [9] and mixed [28] subgroups (see Additional file 19).

- $\mathrm{HCV}$ genotype: genotype $1 / 4(\mathrm{OR}=6.33 ; 95 \% \mathrm{CI}=$ 2.64 to 15.16$)$, genotype $2 / 3(\mathrm{OR}=1.78 ; 95 \% \mathrm{CI}=0.38$ to $8.25)$, and mixed ( $\mathrm{OR}=2.44 ; 95 \% \mathrm{CI}=1.38$ to 4.32$)$. With respect to the $2 / 3$ and mixed genotype, the data came from only two subgroups and two studies respectively (see Additional file 20).

Regarding type of viral infection, all rs12980275 studies dealt with patients with HCV mono-infection, except the report by Grebely et al. [28], in which data from patients with $\mathrm{HCV}$ mono-infection and $\mathrm{HCV} / \mathrm{HIV}$ co-infection were pooled. For this reason, subgroup analyses by type of infection were not carried out.

Using sensitivity analysis (Figure 3 ), we found that the Fischer et al. study [67] on rs12980275 apparently influenced the overall results, and thus a new statistical analysis was performed excluding that paper (data not shown). This influence seemed to affect only genotype $1 / 4$, where heterogeneity was reduced to $0 \%$. Results for genotype $1 / 4$ varied slightly $(\mathrm{OR}=9.13 ; 95 \% \mathrm{CI}=5.84$ to 14.26), although the significance of the OR was not altered. Based on these results and on the population characteristics, we cannot offer any explanation for excluding the Fischer et al. study.

Other single-nucleotide polymorphisms Five polymorphisms (rs11881222, rs7248668, rs8103142, rs8105 790, rs10853728) were only described in three studies or fewer, leading to less robust meta-analysis results (see Additional files 21 to 25). The pooled OR data were 2.99 (95\% CI $=2.31$ to 3.87 ) for rs11881222, 3.87 (95\% CI = 2.74 to 5.47$)$ for rs7248668, $2.62(95 \% \mathrm{CI}=1.97$ to 3.49$)$ for rs8103142, 2.15 (95\% CI = 1.61 to 2.86 ) for rs8105790, and $1.20(95 \% \mathrm{CI}=0.82$ to 1.76$)$ for $\mathrm{rs} 10853728$. There was no heterogeneity except for $\mathrm{rs} 10853728(P=0.061$; $I^{2}=64.3 \%$ ), but we could not perform heterogeneity analysis by subgroup and/or meta-regression because rs10853728 was genotyped in only three of the studies.

We also recorded all the polymorphisms that were studied in only one study each. Twelve SNPs were reported, 


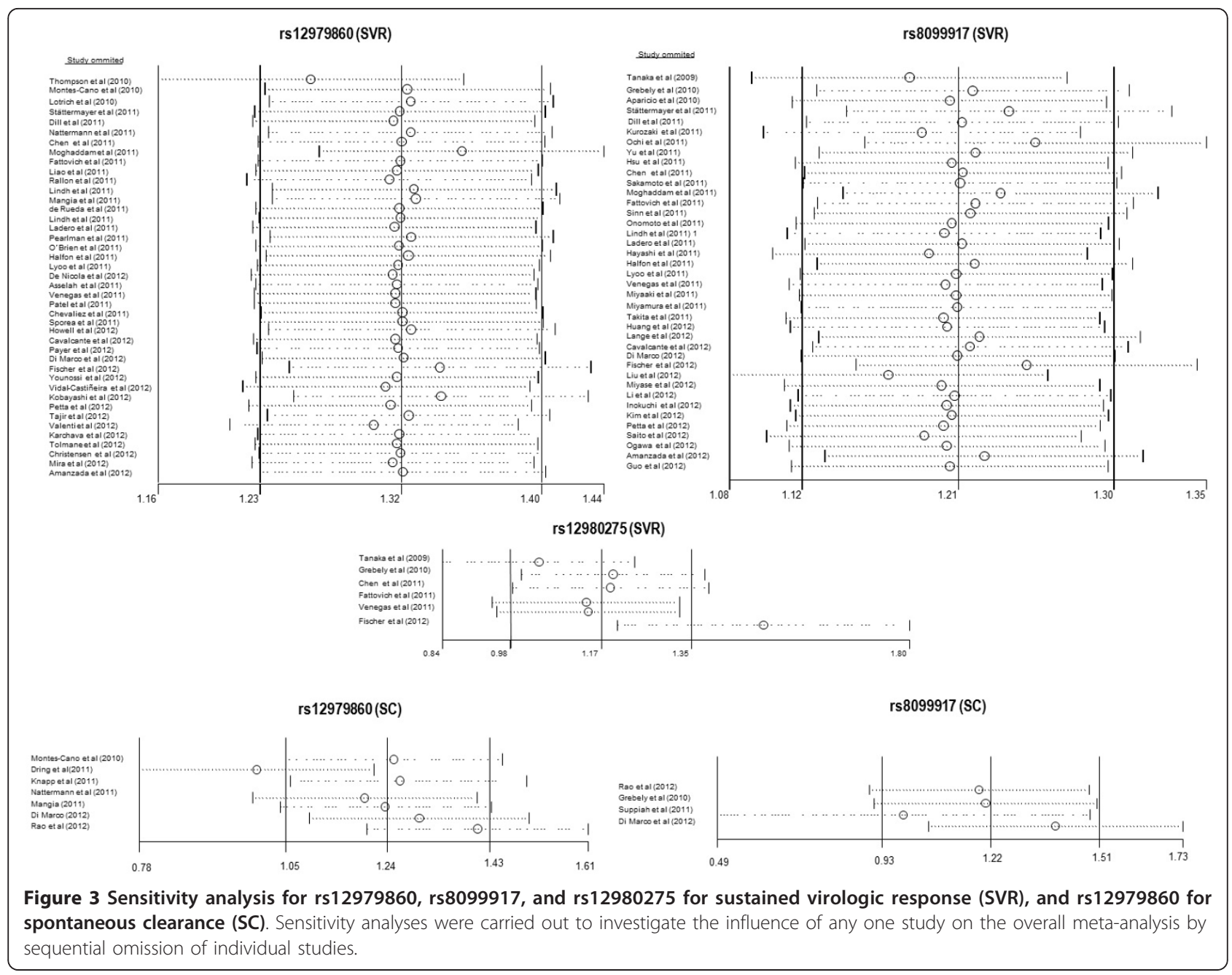

with ORs ranging from 1.19 to 9.96; however, only eight of these were significant (rs35790907 (AA), rs12972991 (AA), rs12982533 (TT), rs688187 (GG), rs4803221 (CC), rs8109886 (CC), rs12980602 (TT), and rs4803219 (CC); see Additional file 26).

Spontaneous clearance

rs12979860 The overall pooled OR was 3.20 (95\% CI = 2.03 to 5.05 ) (Table 1; see Additional file 27). Heterogeneity was detected $\left(P<0.001 ; I^{2}=81.8 \%\right)$, therefore, subgroup analysis was performed based on ethnicity and $\mathrm{HCV}$ genotype.

- Ethnicity: Asians (OR $=1.31 ; 95 \% \mathrm{CI}=0.79$ to 2.15$)$ and Caucasians $(\mathrm{OR}=3.78 ; 95 \% \mathrm{CI}=2.60$ to 5.50 ) (see Additional file 28).

- $\mathrm{HCV}$ genotype: genotype 1 (OR $=5.66 ; 95 \% \mathrm{CI}=$ 3.28 to 9.77$)$, mixed $(\mathrm{OR}=2.34 ; 95 \% \mathrm{CI}=1.48$ to 3.69$)$ and unknown $(\mathrm{OR}=2.96 ; 95 \% \mathrm{CI}=1.75$ to 5.02$)$ (see Additional file 29).

It must be taken into consideration that the results for Asian patients and for genotype 1 correspond to one and two studies, respectively. For Caucasians, a high level of heterogeneity was detected $\left(I^{2}=67.9 \%\right)$.

Sensitivity analysis (Figure 3 ) showed that the study by Dring et al. [88] might be influencing the overall statistical analysis. For this reason, we also analyzed the data after removing this study. The results were similar and the significance of the OR was not altered. Based on these results and to the population characteristics, there was no reason to exclude this study.

rs8099917 Only four studies reported data for rs8099917 (Table 1; see Additional file 30 ). Sensitivity analysis showed that none of the four studies should be omitted from subsequent statistical analysis. Pooled OR was 3.60 ( $95 \% \mathrm{CI}=2.70$ to 4.81 ), and there was no heterogeneity. rs12980275 Two studies reported very different data for rs12980275, leading to non-significant results $(\mathrm{OR}=$ 2.73 ; $95 \% \mathrm{CI}=0.33$ to 22.38 ) and high heterogeneity $\left(I^{2}=81.5 \%\right)$ (Table 1 ; see Additional file 31$)$.

Other single-nucleotide polymorphisms We also recorded all the polymorphisms for SC that were analyzed 


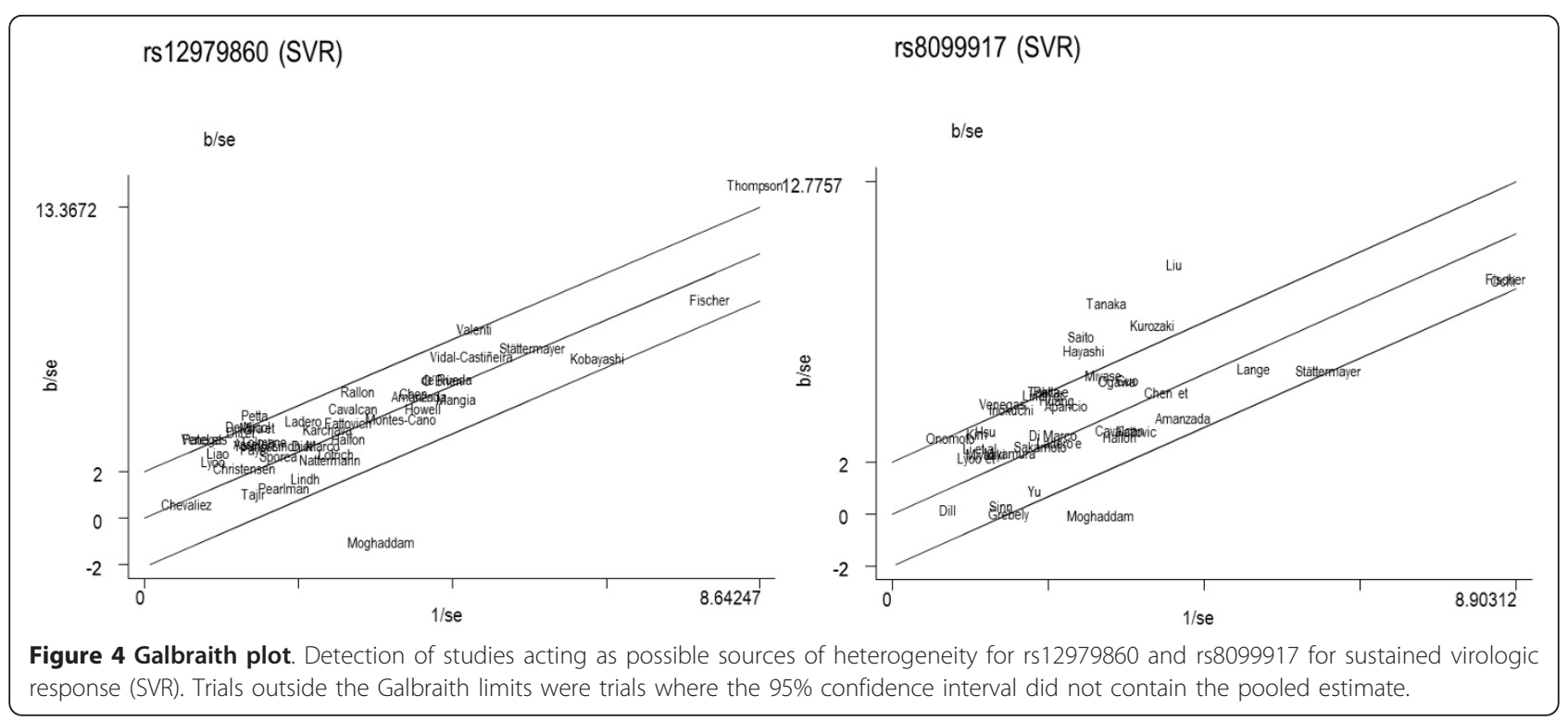

in only one study each. In total, seven SNPs were reported, with ORs ranging from 1.19 to 14.88; however, only four of them (rs10853728 (CC), rs12980275 (AA), rs8105790 (TT), rs8103142 (TT)) were significant, although most of them had very high CIs (see Additional file 32).

\section{Discussion}

There is growing evidence that polymorphisms can contribute to differences in complex disease traits between individuals. Since 2009, several studies have shown that there is an important association between IL28B polymorphisms and HCV clearance. However, the mechanism of this association remains unclear, and is still under study.

To our knowledge, a total of five reviews containing data from meta-analyses have been published to date about the relationship between $I L 28 B$ polymorphisms and SVR [96-100]. The reports of Romero-Gomez et al. and Li et al. are limited because they involved literature searches only up to January and May 2010, respectively, leading to the selection of a low number of studies in both cases (only seven studies). In addition, all metaanalyses were performed for rs12979860 and rs8099917 only. The other three meta-analyses were broader, ranging from 17 to 36 studies. However, all of them analyzed only the effect of the $I L 28 B$ polymorphisms rs12979860 and rs8099917 on SVR by ethnicity and HCV genotype, while the study by Scheiber et al. was limited to HCV genotypes 2 and 3. In addition, the literature searches of these meta-analyses included publications only up to the end of 2011. Consequently, our meta-analysis provides the most up-to-date compilation of studies, including 74 articles, a larger number of SNPs, and association analysis with other clinical situations such as SC. In addition, this is the first meta- analysis investigating the association between $I L 28 B$ polymorphisms and $\mathrm{SC}$, to our knowledge. Therefore, because there has been a very large increase in the number of papers, especially in 2012, it is necessary to assess all data and elucidate controversial or inconclusive results. This meta-analysis has allowed us to estimate the overall OR of all studies, and functions as a robust tool to investigate discrepant results.

Based on the global analysis, there was a significant association between the favorable genotype of seven studied SNPs (rs12979860, rs8099917, rs12980275, rs8105790, rs11881222, rs8103142, and rs7248668) and SVR. In most of the cases, the probability of achieving SVR in patients with a favorable genotype was more than double that in patients with an unfavorable genotype. Although the majority of results had similarities, the magnitude of the association was different in many cases. This could be caused by the different criteria considered in each individual study. For this reason, our meta-analysis focused on displaying general conclusions about the trend of this association. Moreover, we investigated several variables that might contribute to the different magnitude of associations found in different studies.

\section{IL28B and ethnicity}

The significant genetic association of all IL28B SNPs seems to be due to the high linkage disequilibrium (LD) of this genomic region [3-5], which varies across ethnicities. Regarding the Asian population, some authors have described strong LDs between rs12980275, rs8105790, rs11881222, rs8099917, rs7248668, rs10853728, and rs12979860 [5,37]. For Caucasian populations, the results are slightly more diverse depending on the genotyped 
platform used. Thus, Ge et al. [3] reported a strong LD between rs12979860 and rs12980275, whereas Suppiah et al. [4] reported that rs12980275 is strictly linked to rs8105790, rs8103142, rs8109886, and rs8099917. Finally, there was a low LD between rs12979860 and rs12980275 for African Americans $\left(r^{2}=0.56\right)$, whereas for Hispanics, a higher LD $\left(r^{2}=0.88\right)$ was obtained [3]. Our results have shown that in respect to the favorable $I L 28 B$ genotype frequency of rs12979860, there was a marked differential distribution between racial groups (in order from highest to lowest frequency): Asian, Caucasian, North African, Hispanic, African, and African American. Regarding rs8099917, the order was similar, except for African populations, which showed frequencies that were intermediate between Asians and Caucasians, as shown by Thompson et al. [25]. This differential distribution seems to explain much of the observed clinical differences between ethnic groups in response to treatment [101].

We found similar association for rs12979860 for Asians $(\mathrm{OR}=3.27)$ and Caucasians $(\mathrm{OR}=3.63)$. The strength of the association in Asians was almost double that for Caucasians for rs8099917. Similarly, in the case of rs12980275, a larger OR was seen for Asians than for Caucasians. However, rs12980275 was only represented by two studies in Asians and four in Caucasians, therefore the most reliable results and the most robust conclusions were obtained for rs12979860 and rs8099917.

It is also important to note that in our study, the significant association between favorable genotypes and SVR was lost in several instances, such as for rs12979860 in African American and Hispanic patients. However, these data should also be interpreted with caution, because only two studies were included for each ethnicity $[9,25,59]$. Regarding African Americans, the results were right at the limit of significance $(\mathrm{OR}=$ 3.19; $P=0.052$ ), which may be related to the low LD described for African Americans. Owing to the scarcity of available results, new studies in these populations are necessary, especially ones that investigate the effects of different SNPs. For Hispanics, both studies individually showed a significant association, but this significance was lost upon performing the meta-analysis. This could be due to the extremely wide confidence interval of the Venegas et al. study [9]. On the other hand, rs8099917 and rs12980275 seem to be strongly associated for Hispanic populations; however, these results corresponded to only one study, which prevents us from drawing any firm conclusions.

\section{IL28B and hepatitis C virus genotype}

To date, a broad association between favorable $I L 28 B$ genotypes and SVR has been described in patients infected with HCV genotype $1[50,102]$, with a similar association described for genotype 4, although this has been less studied. However, conflicting results have been published about $\mathrm{HCV}$ genotypes $2 / 3$ [33,41]. One of our goals was to discern the pooled significance of such an association, which would have relevance to the decision of initiating therapy. As expected, we found that the favorable genotypes of polymorphisms rs12979860, rs8099917, and rs12980275 were positively associated with SVR for HCV genotypes 1 and 4. Regarding the HCV genotypes 2 and 3, the polymorphisms rs12979860 and rs8099917 showed significant associations. However, the strength of this association was almost three times lower than for genotypes 1 and 4, and in addition, we found that the Asian population was solely responsible for this association in rs8099917. The generally reduced association for patients with $\mathrm{HCV}$ genotypes $2 / 3$ could be related to the high rate of SVR present in these IFNsensitive genotypes, for which larger sample sizes are required to find significant differences [7]. In summary, our findings show that $I L 28 B$ polymorphisms are a strong pre-treatment predictor for SVR in patients with HCV genotypes 1 and 4, but its usefulness is limited for other genotypes.

\section{IL28B and type of viral infection}

The predictive value of $I L 28 B$ polymorphisms has been extensively studied in patients with HCV mono-infection, but only seven eligible studies included patients with HIV/HCV co-infection $[28,29,35,42,61,63,85]$. After stratifying by type of infection, we found that in patients coinfected with $\mathrm{HIV} / \mathrm{HCV}$, the strength of association between rs12979860 and SVR was similar to that for patients with HCV mono-infection. For rs8099917, only the study by Aparicio et al. [29] provided data for patients with HIV/HCV co-infection, which was also divided by HCV genotypes (1, 3, and 4). This study did not show any overall significant association, but when we analyzed the data in more depth, we found differences related to $\mathrm{HCV}$ genotype, with only $\mathrm{HCV}$ genotype 1 being significantly associated with SVR. Therefore, the benefit of $I L 28 B$ genotyping seems to apply to both patients with HCV genotype 1 mono-infection and coinfection. HIV/HCV co-infection could play a significant role in treatment response, but further studies are necessary to confirm this. Again, results should be interpreted with caution.

\section{IL28B polymorphisms and spontaneous clearance of hepatitis $C$ virus}

The identification of markers predicting the persistence of $\mathrm{HCV}$ infection is very important to distinguish between patients whose acute hepatitis $C$ resolves and those who develop a chronic hepatitis $\mathrm{C}$ infection. Roughly, $20 \%$ of patients infected with HCV have SC of 
the virus. The mechanism of this is not clear, but epidemiological, viral, and host factors have all been associated with the difference in HCV clearance likelihood. Thomas et al. [103] showed that rs12979860 strongly enhances the likelihood of clearance of $\mathrm{HCV}$ among individuals of either European or African ancestry. However, to date, few articles about the IL28B polymorphisms involved in SC have been written. Owing to the low number of published articles, we could perform meta-analyses only for rs12979860 and rs8099917. In both cases, a clear association was detected. These results seem completely plausible because all individual studies analyzed showed significant associations for rs12979860 and rs8099917, except for Asian populations, which were represented by only one study [94]. Stratification was possible only for rs12979860. Regarding ethnicity, significant results were obtained only for Caucasians, with similar pooled OR as for SVR.

With respect to $\mathrm{HCV}$ genotype, a strong association was detected for rs12979860 in HCV genotype 1. It has been shown that HCV genotype influences hepatitis $\mathrm{C}$ chronicity, as patients infected with genotype $1 / 4$ who harbor favorable $I L 28 B$ genotypes are less likely to have chronic $\mathrm{HCV}$ infection. By contrast, this protective effect is not seen for infections with either genotypes 2 or 3 [1]. Because of insufficient data, we could not perform a stratified study on other HCV genotypes or ethnicity. Additional studies on these variables are needed to clarify this association.

\section{IL28B polymorphisms as clinical predictors}

During the past number of years, the main focus in $\mathrm{HCV}$ infection has been the identification of markers or factors predicting the likelihood of achieving SVR. Recently, some countries have incorporated IL28B genotyping as a diagnostic criterion in clinical practice [7]. In those patients with unfavorable $I L 28 B$ genotypes, which result in response rates of less than $40 \%$, clinicians may consider deferral of treatment until novel therapies are licensed, something likely to occur soon [7]. However, IL28B genotype is not solely responsible for therapy response. Indeed, our meta-regression data suggested that several other factors such as ethnicity, HCV genotype, and stage of fibrosis might have a significant effect on SVR and/or SC. Recently, a model including IL28B genotype (rs12979860) and four clinical variables (pre-treatment viral load, ratio of alanine and aspartate transaminases, Ishak fibrosis score, and previous treatment with ribavirin) has been developed [51]. This model predicts SVR in patients of European ancestry with HCV genotype 1 who have failed to respond to previous treatment [51]. This algorithm has shown a high predictive ability, but as the authors pointed out, it could be improved in future studies by including other relevant variables such as ethnicity and HCV genotype. Another predictive model has been described for patients with HCV/HIV co-infection, including two hostrelated variables (the IL28B SNP rs12979860 and the level of liver stiffness) and two HCV-related variables (genotype and viral load) [104]. This model was found to have an adequate predictive index, but it could also be enhanced by incorporating HIV variables such as viral load. Apart from the aforementioned variables, it would be of great value for clinical practice if future algorithms could be designed that were applicable to different circumstances, such as naive patients or patients with SC, for instance.

\section{Future directions}

The number of studies on new antiviral therapies have risen in the past few years. Therefore, it would have been interesting to investigate whether IL28B polymorphisms also play a predictive role in novel therapies such as direct-acting antivirals (DAAs). However, it was not been possible here because only a few studies have been published that include data on novel therapies. Our literature search returned five studies involving triple therapy. Three of them involved standard of care (PEG-IFN/RBV) with inclusion of telaprevir in the same cohort [105-107], while the fourth studied the inclusion of danoprevir [108], and the fifth studied the inclusion of boceprevir [109]. As we could not perform meta-analysis on these, all of these were excluded. These therapies, which are based on protease inhibitors, are the most advanced DAAs in clinical development. However, any influence of $I L 28 B$ polymorphisms on the outcome of these novel therapies is not clear. These few studies have shown that, regardless of treatment history, IL28B SNPs seem to enhance rapid, early, and SVR when combined with PEG-IFN/RBV in patients with chronic HCV genotype 1 infection $[109,110]$. Further studies are needed to clarify this association.

Finally, to properly interpret our results, some considerations have to be taken into account. Our meta-analysis was performed by using the unadjusted raw data provided from each study, whereas most of the results given by the authors were previously adjusted by age, fibrosis stage, HCV viral load, and/or other factors. For this reason, our ORs may differ slightly from those cited by the original articles. For rs8099917, we identified publication bias, which could indicate that smaller studies dealing with this SNP could have been more likely to be published if their results were significant than if their results were negative or inconclusive. When heterogeneity was evaluated, studies were stratified by ethnicity, genotype, and type of infection, but in some cases heterogeneity remained, indicating the possibility that different causes of heterogeneity may exist. As we have previously mentioned, the number of studies in some subgroup analyses was too small, which led to weak results. As for the five least studied polymorphisms (rs11881222, rs7248668, 
rs8103142, rs8105790, rs10853728), results are limited and new studies are still needed. Consequently, these results should be interpreted with caution.

\section{Conclusions}

$I L 28 B$ polymorphisms influence both IFN treatment outcomes and the natural clearance of $\mathrm{HCV}$ infection. However, although we cannot provide a biological explanation, our findings indicate the most adequate genetic marker seems to vary depending on ethnicity, HCV genotype, and type of viral infection. Taking into account the most robust analyses, the SNP most associated with SVR in Caucasians was rs12979860, whereas in Asians it seemed to be rs8099917. However, for Africans, African Americans, North Africans, and Hispanics, extensive studies are still needed. After analyzing the conflicting results described above for genotypes 2 and 3, our data seem to indicate that rs8099917 is apparently the most adequate predictive marker for SVR with these genotypes. For patients with $\mathrm{HCV} / \mathrm{HIV}$ co-infection, the most studied SNP (rs12979860) gave similar results to those seen for patients with $\mathrm{HCV}$ mono-infection patients. Finally, both rs12979860 and rs8099917 were clearly associated with SC. Moreover, because IL28B genotyping needs be performed only once in a patient's life, it is relatively cheap and provides high predictive value. $I L 28 B$ polymorphisms could thus be used to perform personalized treatment in clinical practice, which could play a substantial role in the selection of candidates for standard treatment versus triple therapy with DAAs.

\section{Additional material}

Additional file 1: Figure S1, Search terms. Relevant studies were identified by a literature search of PubMed without imposing study period restrictions.

Additional file 2: Table S1, Summary of characteristics of all studies included for pegylated interferon- $\alpha$ plus ribavirin (PEG-IFN/RBV) treatment outcome and spontaneous clearance. * Data belongs to original sample size, not to the genotyped subpopulation. Abbreviations: A, African; AA, African American; As, Asian; C, Caucasian; H, Hispanic; NA, North African; ND, no data; $R C T$, randomized controlled trial.

Additional file 3: Table S2, Quality appraisal for meta-analysis of sustained virologic response (SVR). 1) Source population well described? 2) Population well described and appropriate? 3) Did participants represent those eligible? 4) Was information on previous hepatitis C virus (HCV) treatment information reported? 5) Inclusion/ exclusion criteria reported? 6) Type of treatment well described? 7) Outcome measures well described and without incongruencies? 8) Outcome measurement complete? (That is, all genotype counts reported?) 9) Assessment of Hardy-Weinberg equilibrium? 10) Description of what genetic model was assumed? 11) Consideration of genotyping errors and confirmation of results? 12) Information of linkage disequilibrium? 13) Information on haplotypes? 14) Responder and nonresponder groups comparison at baseline? 15) Raw data given or calculable? 16) Study sufficiently powered? 17) Statistical methods appropriate? 18) Study results internally valid (that is, unbiased)? (Summary of items 5 to 8 and 14 to 17)? 19) Genetic study reliable? (Summary of items 9 to 13). 20) Results generalizable to the source population (that is, external validity)? (Summary of items 1 to 4). 21) Overall study quality? Abbreviations: NA, not applicable; NR, not reported.

Additional file 4: Table S3, Quality appraisal for SC meta-analysis. 1) Source population well described? 2) Population well described and appropriate? 3) Did participants represent those eligible? 4)? Was information on previous hepatitis C virus (HCV) reported? 5) Inclusion/ exclusion criteria reported? 6) Type of treatment well described? 7) Outcome measures well described and without incongruencies? 8) Outcome measurement complete? (That is, all genotype counts reported?) 9) Assessment of Hardy-Weinberg equilibrium? 1) Description of what genetic model was assumed? 11) Consideration of genotyping errors and confirmation of results? 12) Information on linkage disequilibrium? 13) Information on haplotypes? 14) Spontaneous responder and non-responder groups comparison at baseline? 15? Raw data given or calculable? 16) Study sufficiently powered? 17) Statistical methods appropriate? 18) Study results internally valid (that is, unbiased)? (summary of items 5 to 8 and 14 to 17.) 19) Genetic study reliable? (summary of items 9 to 13.) 20) Results generalizable to the source population (that is, external validity)? (summary of items 1 to 4.) 21) Overall study quality? Abbreviations: NA, not applicable; NR, not reported.

Additional file 5: Figure S2, The location of the studied singlenucleotide polymorphisms (SNPs) in the genome. * SNPs most studied in recent years.

Additional file 6: Table S4, Identification of all subgroups available for each study.

Additional file 7: Table S5, Egger test result bias for rs 12979860 and rs8099917 for sustained virologic response (SVR). No., number of studies; Coef., asymmetry regression coefficient; Std. Err., standard error; $t$, statistic; $P>|t|$, significance; and $95 \% \mathrm{Cl}$, confidence interval. Coef. corresponds to the intercept value in the regression equation, which estimates the asymmetry of the funnel plot. Positive values (Coef. $>0$ ) indicate higher levels of effect size in studies with smaller sample sizes.

Additional file 8: Table S6, Genotype and allele frequencies stratified by ethnicity for all the polymorphisms included in the meta-analysis. (a) Sustained virologic response (SVR) and (b) spontaneous clearance (SC).Abbreviations: A, African; AA, African American; As, Asian; C, Caucasian; H, Hispanic; NA, North African; n.d., no data available. Favorable genotypes: rs12979860 (CC), rs8099917 (TT), rs12980275 (AA), rs8105790 (TT), rs11881222 (AA), rs8103142 (TT), rs7248668 (GG). There is conflicting information for rs 10853728 .

Additional file 9: Figure S3, Overall forest plot showing the association of rs12979860 with sustained virologic response (SVR) The vertical continuous line indicates no difference for SVR regarding IL28B genotype. The size of each square denotes the proportion of information provided by each trial. Pooled odds ratios were calculated from random-effects models with the DerSimonian-Laird method. (a) The number of patients with the favorable genotype (CC) who achieved SVR with respect to the total number of patients having the favorable genotype. (b) The number of patients with the unfavorable genotype $(\mathrm{CT}+\mathrm{TT})$ who achieved SVR with respect to the total number of patients having the unfavorable genotype. The dashed vertical red line represents overall OR.

Additional file 10: Figure S4, Forest plot showing the association between rs12979860 and sustained virologic response (SVR) stratified by ethnicity. See description in Figure S3.

Additional file 11: Figure S5, Forest plot showing the association between rs12979860 and sustained virologic response (SVR) stratified by hepatitis $\mathrm{C}$ virus (HCV) genotype. See description in Figure S3.

Additional file 12: Table S7, Subgroup analysis by ethnicity and hepatitis C virus (HCV) genotype (pooled odds ratio and $95 \%$ confidence interval). $\neq$ Data from only one study. ${ }^{*} P<0.05 ;{ }^{* *} P<$ 0.001. Abbreviations: A, African; AA, African American; As, Asian; C, Caucasian; H, Hispanic; n.d., no data available.

Additional file 13: Figure S6, Forest plot showing the association between rs12979860 and sustained virologic response (SVR), 
stratified by type of infection: hepatitis $\mathrm{C}$ virus (HCV) monoinfection and HCV/HIV co-infection. For details, see main description in Figure S3.

Additional file 14: Figure S7, Overall forest plot showing the association between rs8099917 and sustained virologic response (SVR). Superscripts: number of patients with (a) favorable genotype (TT) or (b) unfavorable genotype (TG+GG) who achieved SVR, with respect to the total number of patients with the favorable or unfavorable genotype, respectively. For extended details, see main description in Figure S3.

Additional file 15: Figure S8, Forest plot showing the association between rs8099917 and sustained virologic response (SVR), stratified by ethnicity. Superscripts: number of patients with (a) favorable genotype (TT) or (b) unfavorable genotype (TG+GG) who achieved SVR, with respect to the total number of patients having the favorable or unfavorable genotype, respectively. For complete details, see main description in Figure $\mathrm{S} 3$.

Additional file 16: Figure S9, Forest plot showing the association between rs8099917 and sustained virologic response (SVR) stratified by hepatitis C virus (HCV) genotype. Superscripts: number of patients with (a) favorable genotype (TT) or (b) unfavorable genotype $(\mathrm{TG}+\mathrm{GG})$ who achieved SVR with respect to the total number of patients having the favorable or unfavorable genotype, respectively. For complete details, see main description in Figure S3.

Additional file 17: Figure S10, Overall forest plot showing the association between rs8099917 and sustained virologic response (SVR) stratified by type of infection: hepatitis C virus (HCV) monoinfection and HCV/HIV co-infection. Superscripts: number of patients with (a) favorable genotype (TT) or (b) unfavorable genotype (TG+GG) who achieved SVR, with respect to the total number of patients having the favorable or unfavorable genotype, respectively. For extended details, see main description in Figure S3.

Additional file 18: Figure S11, Overall forest plot showing the association between rs 12980275 and sustained virologic response (SVR). Superscripts: number of patients with (a) favorable genotype (AA) or (b) unfavorable genotype (AG+GG) who achieved SVR, with respect to the total number of patients having the favorable or unfavorable genotype, respectively. For extended details, see main description in Figure S3.

Additional file 19: Figure S12, Forest plot showing the association between rs 12980275 and sustained virologic response (SVR), stratified by ethnicity. Superscripts: number of patients with (a) favorable genotype (AA) or (b) unfavorable genotype (AG+GG) who achieved SVR, with respect to the total number of patients having the favorable or unfavorable genotype, respectively. For extended details, see main description in Figure S3.

Additional file 20: Figure S13, Forest plot showing the association between rs12980275 and sustained virologic response (SVR) stratified by hepatitis $\mathrm{C}$ virus (HCV) genotype. Superscripts: number of patients with (a) favorable genotype (AA) or (b) unfavorable genotype $(A G+G G)$ who achieved SVR, with respect to the total number of patients having the favorable or unfavorable genotype, respectively. For extended details, see main description in Figure S3.

Additional file 21: Figure S14, Overall forest plot showing the association between rs11881222 and sustained virologic response (SVR). Pooled odds ratios were calculated from fixed-effects models with the Mantel-Haenszel method. Superscripts: number of patients with (a) favorable genotype (AA) or (b) unfavorable genotype (AG+GG) who achieved SVR, with respect to the total number of patients having the favorable or unfavorable genotype, respectively. For extended details, see main description in Figure S3.

Additional file 22: Figure S15, Overall forest plot showing the association between rs7248668 and sustained virologic response (SVR). Pooled odds ratios were calculated from fixed-effect models with the Mantel-Haenszel method. Superscripts: number of patients with (a) favorable genotype (GG) or (b) unfavorable genotype (GA+AA) who achieved SVR, with respect to the total number of patients having the favorable or unfavorable genotype, respectively For extended details, see main description in Figure S3.
Additional file 23: Figure S16, Overall forest plot showing the association between rs8103142 and sustained virologic response (SVR). Pooled odds ratios were calculated from fixed-effect models with the Mantel-Haenszel method. Superscripts: number of patients with (a) favorable genotype (TT) or (b) unfavorable genotype (TC+CC) who achieved SVR, with respect to the total number of patients having the favorable or unfavorable genotype, respectively. For extended details, see main description in Figure S3.

Additional file 24: Figure S17, Overall forest plot showing the association between rs8105790 and sustained virologic response (SVR). Pooled odds ratios were calculated from fixed-effect models with the Mantel-Haenszel method. Superscripts: number of patients with (a) favorable genotype (TT) or (b) unfavorable genotype (TC+CC) who achieved SVR, with respect to the total number of patients having the favorable or unfavorable genotype, respectively. For extended details, see main description in Figure $\mathrm{S} 3$.

Additional file 25: Figure S18, Overall forest plot showing the association between rs 10853728 and sustained virologic response (SVR). Superscripts: number of patients with (a) favorable genotype (CC) or (b) unfavorable genotype (CG+GG) who achieved SVR, with respect to the total number of patients having the favorable or unfavorable genotype, respectively. For extended details, see main description in Figure S3.

Additional file 26: Figure S19, Forest plot showing the associations between interleukin 28B (IL28B) gene polymorphisms reported in only one study and sustained virologic response (SVR). Superscripts: number of patients with (a) favorable genotype (CC) or (b) unfavorable genotype $(\mathrm{CG}+\mathrm{GG})$ who achieved SVR with respect to the total number of patients having the favorable or unfavorable genotype, respectively. * Single-nucleotide polymorphisms (SNPs) from Smith et al article; + SNPS from Chen et al article.

Additional file 27: Figure S20, Overall forest plot showing the association between rs 12979860 and spontaneous clearance (SC). The vertical continuous line indicates no difference in SC for the interleukin 28B (IL28B) genotype. Pooled odds ratios were calculated from random-effects models with the DerSimonian-Laird method. (a) The number of patients with favorable genotype who achieved SC, with respect to the total number of patients having the favorable genotype. (b) The number of patients with unfavorable genotype who achieved SC, with respect to the total number of patients having the unfavorable genotype. For complete details, see main description in Figure S3.

Additional file 28: Figure S21, Forest plot showing the association between rs12979860 and spontaneous clearance (SC) stratified by ethnicity. The vertical continuous line indicates no difference in SC for the interleukin 28B (IL28B) genotype. Pooled odds ratios were calculated from random-effects models with the DerSimonian-Laird method. (a) The number of patients with the favorable genotype who achieved SC, with respect to the total number of patients having the favorable genotype. (b) The number of patients with unfavorable genotype who achieved SC, with respect to the total number of patients having the unfavorable genotype. For complete details, see main description in Figure S3.

Additional file 29: Figure S22, Forest plot showing the association between rs 12979860 and spontaneous clearance (SC) stratified by hepatitis $\mathrm{C}$ virus (HCV) genotype. The vertical continuous line indicates no difference in SC for interleukin 28B (IL28B) gene genotype. Pooled odds ratios were calculated from random-effects models with the DerSimonian-Laird method. (a) The number of patients with favorable genotype who achieved SC, with respect to the total number of patients having the favorable genotype. (b) The number of patients with unfavorable genotype who achieved SC, with respect to the total number of patients having the unfavorable genotype. For complete details, see main description in Figure S3.

Additional file 30: Figure S23, Forest plot showing the association between rs8099917 and spontaneous clearance (SC). The vertical continuous line indicates no difference in SC for the interleukin $28 B$ (IL28B) genotype. Pooled odds ratios were calculated from fixed-effect models with the Mantel-Haenszel method. (a) The number of patients with the favorable genotype who achieved SC, with respect to the total 
number of patients having the favorable genotype. (b) The number of patients with the unfavorable genotype who achieved SC, with respect to the total number of patients having the unfavorable genotype. For complete details, see main description in Figure 3.

Additional file 31: Figure S24, Forest plot showing the association between rs12980275 and spontaneous clearance (SC). The vertical continuous line indicates no difference in SC for the interleukin 28B (L28B) genotype. Pooled odds ratios were calculated from random-effects models with the DerSimonian-Laird method. (a) The number of patients with the favorable genotype who achieved SC, with respect to the total number of patients having the favorable genotype. (b) The number of patients with the unfavorable genotype who achieved SC, with respect to the total number of patients having the unfavorable genotype. For complete details, see main description in Figure 3.

Additional file 32: Figure S25, Forest plot showing the associations between interleukin 28B (IL28B) gene polymorphisms reported in only one study and spontaneous clearance (SC). For extended details, see main description in Figure S3.

\section{Abbreviations}

Cl: confidence interval; DAA: direct-acting antiviral; HCV: Hepatitis C virus; HIV: human immunodeficiency virus; $P^{2}$ : value that provides a measure of the degree of heterogeneity; IL28B: interleukin 28B gene; ISGs: interferonstimulated genes; LD: linkage disequilibrium; OR: odds ratio; PEG-IFN/RBV: pegylated interferon-a plus ribavirin; SC: spontaneous clearance; SNP: singlenucleotide polymorphism; SVR: sustained virologic response.

\section{Authors' contributions}

MAJS, AF, and SR designed the study. MAJS and AF collected all data, performed the statistical analysis, and drafted the report. MAJS, AFR, MGA, MGF, and SR interpreted the data and critically reviewed the report. All authors have approved the final version of the manuscript.

\section{Competing interests}

The authors declare that they have no competing interests.

\section{Acknowledgements}

We thank those authors of the studies included in this review for providing additional information upon request. We also are grateful to Cristina Asensio and Rocío Carmona for valuable help with the Stata software. We thank D. Aurelio Tobías for his valuable suggestions and help with heterogeneity analyses. We thank the reviewers for their suggestions and useful comments. This work was supported by grants from the 'Health Institute Carlos III (ISCIII)' [PI08/0738 and PI11/00245]. MAJS, AFR MGF and MGA were supported by the after grants [CM10/00105, PI08/0738, CM09/00031, and CM08/00101 respectively].

Received: 23 April 2012 Accepted: 8 January 2013

Published: 8 January 2013

\section{References}

1. Soriano V, Poveda E, Vispo E, Labarga P, Rallon N, Barreiro P: Pharmacogenetics of hepatitis C. J Antimicrob Chemother 2012, 67:523-529.

2. Hadigan C, Kottilil S: Hepatitis C virus infection and coinfection with human immunodeficiency virus: challenges and advancements in management. JAMA 2011, 306:294-301.

3. Ge D, Fellay J, Thompson AJ, Simon JS, Shianna KV, Urban TJ, Heinzen EL, Qiu P, Bertelsen AH, Muir AJ, Sulkowski M, McHutchison JG, Goldstein DB: Genetic variation in IL28B predicts hepatitis C treatment-induced viral clearance. Nature 2009, 461:399-401.

4. Suppiah V, Moldovan M, Ahlenstiel G, Berg T, Weltman M, Abate ML, Bassendine M, Spengler U, Dore GJ, Powell E, Riordan S, Sheridan D, Smedile A, Fragomeli V, Müller T, Bahlo M, Stewart GJ, Booth DR, George J: IL28B is associated with response to chronic hepatitis C interferon-alpha and ribavirin therapy. Nat Genet 2009, 41:1100-1104.
5. Tanaka Y, Nishida N, Sugiyama M, Kurosaki M, Matsuura K, Sakamoto N, Nakagawa M, Korenaga M, Hino K, Hige S, Ito Y, Mita E, Tanaka E, Mochida S, Murawaki Y, Honda M, Sakai A, Hiasa Y, Nishiguchi S, Koike A, Sakaida I, Imamura M, Ito K, Yano K, Masaki N, Sugauchi F, Izumi N, Tokunaga K, Mizokami M: Genome-wide association of IL28B with response to pegylated interferon-alpha and ribavirin therapy for chronic hepatitis C. Nat Genet 2009, 41:1105-1109.

6. Marcello T, Grakoui A, Barba-Spaeth G, Machlin ES, Kotenko SV, MacDonald MR, Rice CM: Interferons alpha and lambda inhibit hepatitis C virus replication with distinct signal transduction and gene regulation kinetics. Gastroenterology 2006, 131:1887-1898.

7. Holmes JA, Desmond PV, Thompson AJ: Redefining baseline demographics: the role of genetic testing in hepatitis C virus infection. Clin Liver Dis 2011, 15:497-513.

8. Afdhal NH, McHutchison JG, Zeuzem S, Mangia A, Pawlotsky JM, Murray JS, Shianna KV, Tanaka Y, Thomas DL, Booth DR, et al: Hepatitis C pharmacogenetics: state of the art in 2010. Hepatology 2010, 53:336-345.

9. Venegas M, Villanueva RA, Gonzalez K, Brahm J: IL28B polymorphisms associated with therapy response in Chilean chronic hepatitis $C$ patients. World J Gastroenterol 2011, 17:3636-3639.

10. Patel K, Lucas JE, Thompson JW, Dubois LG, Tillmann HL, Thompson AJ, Uzarski D, Califf RM, Moseley MA, Ginsburg GS, McHutchison JG, McCarthy JJ: High predictive accuracy of an unbiased proteomic profile for sustained virologic response in chronic hepatitis C patients. Hepatology 2011, 53:1809-1818.

11. Moghaddam A, Melum E, Reinton N, Ring-Larsen H, Verbaan H, Bjoro K, Dalgard O: IL28B genetic variation and treatment response in patients with hepatitis C virus genotype 3 infection. Hepatology 2011, 53:746-754

12. Sutton AJ, Abrams KR, Jones DR: An illustrated guide to the methods of meta-analysis. Journal of evaluation in clinical practice 2001, 7:135-148.

13. Moher D, Liberati A, Tetzlaff J, Altman DG: Preferred reporting items for systematic reviews and meta-analyses: the PRISMA statement. PLoS Med 2009, 6:e1000097.

14. Jorde LB, Wooding SP: Genetic variation, classification and 'race'. Nat Genet 2004, 36:S28-33.

15. Ghany MG, Strader DB, Thomas DL, Seeff LB: Diagnosis, management, and treatment of hepatitis C: an update. Hepatology 2009, 49:1335-1374.

16. Jackson R, Ameratunga S, Broad J, Connor J, Lethaby A, Robb G, Wells S, Glasziou P, Heneghan C: The GATE frame: critical appraisal with pictures. Evidence-based nursing 2006, 9:68-71.

17. Rohlfs RV, Weir BS: Distributions of Hardy-Weinberg equilibrium test statistics. Genetics 2008, 180:1609-1616.

18. Mantel N, Haenszel W: Statistical aspects of the analysis of data from retrospective studies of disease. J Natl Cancer Inst 1959, 22:719-748.

19. DerSimonian $R$, Kacker $R$ : Random-effects model for meta-analysis of clinical trials: an update. Contemporary clinical trials 2007, 28:105-114.

20. Oxman AD, Guyatt GH: A consumer's guide to subgroup analyses. Ann Intern Med 1992, 116:78-84.

21. Tobias A: A graphical display useful for meta-analysis: a comment. European Journal of Public Health 1998, 8:91-92.

22. Galbraith RF: A note on graphical presentation of estimated odds ratios from several clinical trials. Statistics in medicine 1988, 7:889-894.

23. Harbord RM, Egger M, Sterne JA: A modified test for small-study effects in meta-analyses of controlled trials with binary endpoints. Statistics in medicine 2006, 25:3443-3457.

24. Copas J, Shi JQ: Meta-analysis, funnel plots and sensitivity analysis. Biostatistics 2000, 1:247-262.

25. Thompson AJ, Muir AJ, Sulkowski MS, Ge D, Fellay J, Shianna KV, Urban T, Afdhal NH, Jacobson IM, Esteban R, et al: Interleukin-28B polymorphism improves viral kinetics and is the strongest pretreatment predictor of sustained virologic response in genotype 1 hepatitis $C$ virus. Gastroenterology 2010, 139:120-129, e118.

26. Montes-Cano MA, Garcia-Lozano JR, Abad-Molina C, Romero-Gomez M, Barroso N, Aguilar-Reina J, Nunez-Roldan A, Gonzalez-Escribano MF: Interleukin-28B genetic variants and hepatitis virus infection by different viral genotypes. Hepatology 2010, 52:33-37.

27. Stattermayer AF, Stauber R, Hofer H, Rutter K, Beinhardt S, Scherzer TM, Zinober K, Datz C, Maieron A, Dulic-Lakovic E, Kessler HH, Steindl-Munda P, Strasser M, Krall C, Ferenci P: Impact of IL28B genotype on the early and sustained virologic response in treatment-naive patients with chronic hepatitis C. Clinical gastroenterology and hepatology 2011, 9:344-350. 
28. Grebely J, Petoumenos K, Hellard M, Matthews GV, Suppiah V, Applegate T, Yeung B, Marks P, Rawlinson W, Lloyd AR, et al: Potential role for interleukin-28B genotype in treatment decision-making in recent hepatitis C virus infection. Hepatology 2011, 52:1216-1224.

29. Aparicio E, Parera M, Franco S, Perez-Alvarez N, Tural C, Clotet B, Martinez MA: IL28B SNP rs8099917 is strongly associated with pegylated interferon-alpha and ribavirin therapy treatment failure in HCV/HIV-1 coinfected patients. PloS one 2010, 5:e13771.

30. Dill MT, Duong FH, Vogt JE, Bibert S, Bochud PY, Terracciano L, Papassotiropoulos A, Roth V, Heim MH: Interferon-induced gene expression is a stronger predictor of treatment response than IL28B genotype in patients with hepatitis C. Gastroenterology 2011, 140:1021-1031.

31. Kurosaki M, Tanaka Y, Nishida N, Sakamoto N, Enomoto N, Honda M, Sugiyama M, Matsuura K, Sugauchi F, Asahina Y, Nakagawa M, Watanabe M, Sakamoto M, Maekawa S, Sakai A, Kaneko S, Ito K, Masaki N, Tokunaga K, Izumi N, Mizokami M: Pre-treatment prediction of response to pegylatedinterferon plus ribavirin for chronic hepatitis $C$ using genetic polymorphism in IL28B and viral factors. Journal of hepatology 2011, 54:439-448.

32. Lotrich FE, Loftis JM, Ferrell RE, Rabinovitz M, Hauser P: IL28B polymorphism is associated with both side effects and clearance of hepatitis C during interferon-alpha therapy. Journal of interferon \& cytokine research 2010

33. Ochi H, Maekawa T, Abe H, Hayashida Y, Nakano R, Imamura M, Hiraga N, Kawakami Y, Aimitsu S, Kao JH, Kubo M, Tsunoda T, Kumada H, Nakamura $Y$, Hayes CN, Chayama K: IL-28B predicts response to chronic hepatitis $C$ therapy-fine-mapping and replication study in Asian populations. The Journal of general virology 2011, 92:1071-1081.

34. Yu ML, Huang CF, Huang JF, Chang NC, Yang JF, Lin ZY, Chen SC, Hsieh MY, Wang LY, Chang WY, Li YN, Wu MS, Dai CY, Juo SH, Chuang WL: Role of interleukin-28B polymorphisms in the treatment of hepatitis $\mathrm{C}$ virus genotype 2 infection in Asian patients. Hepatology 2011, 53:7-13.

35. Nattermann J, Vogel M, Nischalke HD, Danta M, Mauss S, Stellbrink HJ, Baumgarten A, Mayr C, Bruno R, Tural C, Klausen G, Clotet B, Naumann U, Lutz T, Rausch M, Schewe K, Bienek B, Haerter G, Sauerbruch T, Rockstroh JK, Spengler U: Genetic variation in IL28B and treatmentinduced clearance of hepatitis C virus in HIV-positive patients with acute and chronic hepatitis C. J Infect Dis 2010, 203:595-601

36. Hsu CS, Hsu SJ, Chen HC, Tseng TC, Liu CH, Niu WF, Jeng J, Liu CJ, Lai MY, Chen PJ, Kao JH, Chen DS: Association of IL28B gene variations with mathematical modeling of viral kinetics in chronic hepatitis $C$ patients with IFN plus ribavirin therapy. Proc Natl Acad Sci USA 2011, 108:3719-3724.

37. Chen JY, Lin CY, Wang CM, Lin YT, Kuo SN, Shiu CF, Chang SW, Wu J, Sheen IS: IL28B genetic variations are associated with high sustained virological response (SVR) of interferon-alpha plus ribavirin therapy in Taiwanese chronic HCV infection. Genes Immun 2011, 12:300-309.

38. Sakamoto N, Nakagawa M, Tanaka Y, Sekine-Osajima Y, Ueyama M, Kurosaki M, Nishida N, Tamori A, Yuki NS, Itsui Y, Azuma S, Kakinuma S, Hige S, Itoh Y, Tanaka E, Hiasa Y, Izumi N, Tokunaga K, Mizokami M, Watanabe M: Association of IL28B variants with response to pegylatedinterferon alpha plus ribavirin combination therapy reveals intersubgenotypic differences between genotypes $2 \mathrm{a}$ and $2 \mathrm{~b}$. Journal of medical virology 2011, 83:871-878.

39. Fattovich G, Covolo L, Bibert S, Askarieh G, Lagging M, Clement S, Malerba G, Pasino M, Guido M, Puoti M, Gaeta GB, Santantonio T, Raimondo G, Bruno R, Bochud PY, Donato F, Negro F: IL28B polymorphisms, IP-10 and viral load predict virological response to therapy in chronic hepatitis C. Aliment Pharmacol Ther 2011, 33:1162-1172.

40. Liao XW, Ling Y, Li XH, Han Y, Zhang SY, Gu LL, Yu DM, Yao BL, Zhang DH, Jin GD, Lu ZM, Gong QM, Zhang XX: Association of genetic variation in IL28B with hepatitis C treatment-induced viral clearance in the Chinese Han population. Antiviral therapy 16:141-147.

41. Sinn DH, Kim YJ, Lee ST, Gwak GY, Choi MS, Lee JH, Koh KC, Yoo BC, Paik SW: Association of a single nucleotide polymorphism near the interleukin-28B gene with response to hepatitis C therapy in Asian patients. Journal of gastroenterology and hepatology 2011, 26:1374-1379.

42. Rallon NI, Soriano V, Naggie S, Restrepo C, Goldstein D, Vispo E, McHutchison J, Benito JM: IL28B gene polymorphisms and viral kinetics in HIV/hepatitis C virus-coinfected patients treated with pegylated interferon and ribavirin. AIDS 2011, 25:1025-1033.

43. Onomoto K, Morimoto S, Kawaguchi T, Toyoda H, Tanaka M, Kuroda M, Uno K, Kumada T, Matsuda F, Shimotohno K, Fujita T, Murakami Y: Dysregulation of IFN system can lead to poor response to pegylated interferon and ribavirin therapy in chronic hepatitis C. PloS one 2011, 6:e19799.

44. Lindh M, Lagging M, Farkkila M, Langeland N, Morch K, Nilsson S, Norkrans G, Pedersen C, Buhl MR, Westin J, Hellstrand K: Interleukin 28B gene variation at rs12979860 determines early viral kinetics during treatment in patients carrying genotypes 2 or 3 of hepatitis $C$ virus. J Infect Dis 2011, 203:1748-1752.

45. Mangia A, Thompson AJ, Santoro R, Piazzolla V, Copetti M, Minerva N, Petruzzellis D, Mottola L, Bacca D, McHutchison JG: Limited use of interleukin $28 \mathrm{~B}$ in the setting of response-guided treatment with detailed on-treatment virological monitoring. Hepatology 2011, 54:772-780.

46. de Rueda PM, Lopez-Nevot MA, Saenz-Lopez P, Casado J, Martin-Casares A, Palomares P, Quiles R, Gila A, Romero-Gomez M, Pavon EJ, Muñoz JA, Carazo A, Sanz-Cameno P, Moreno-Otero R, Diago M, León J, RuizExtremera A, Salmerón J: Importance of host genetic factors HLA and IL28B as predictors of response to pegylated interferon and ribavirin. Am J Gastroenterol 2011, 106:1246-1254.

47. Lindh M, Lagging M, Arnholm B, Eilard A, Nilsson S, Norkrans G, Soderholm J, Wahlberg T, Wejstal R, Westin J, Hellstrand K: IL28B polymorphisms determine early viral kinetics and treatment outcome in patients receiving peginterferon/ribavirin for chronic hepatitis $\mathrm{C}$ genotype 1. J Viral Hepat 2011, 18:e325-331.

48. Ladero JM, Martin EG, Fernandez C, Carballo M, Devesa MJ, Martinez C, Suarez A, Diaz-Rubio M, Agundez JA: Predicting response to therapy in chronic hepatitis C: an approach combining IL28B gene polymorphisms and clinical data. Journal of gastroenterology and hepatology 2012, 27:279-85.

49. Pearlman $\mathrm{BL}$, Ehleben $\mathrm{C}$ : The IL-28B genotype predicts which slowresponding hepatitis $\mathrm{C}$-infected patients will benefit from treatment extension. Am J Gastroenterol 2011, 106:1370-1371.

50. Hayashi K, Katano Y, Honda T, Ishigami M, Itoh A, Hirooka Y, Ishikawa T, Nakano I, Yoshioka K, Toyoda H, Kumada T, Goto H: Association of interleukin $28 \mathrm{~B}$ and mutations in the core and NS5A region of hepatitis $C$ virus with response to peg-interferon and ribavirin therapy. Liver international 2011, 31:1359-1365.

51. O'Brien TR, Everhart JE, Morgan TR, Lok AS, Chung RT, Shao Y, Shiffman ML, Dotrang M, Sninsky JJ, Bonkovsky HL, et al: An IL28B genotype-based clinical prediction model for treatment of chronic hepatitis C. PloS one 2011, 6:e20904.

52. Smith KR, Suppiah V, O'Connor K, Berg T, Weltman M, Abate ML, Spengler U, Bassendine M, Matthews G, Irving WL, Powell E, Riordan S, Ahlenstiel G, Stewart GJ, Bahlo M, George J, Booth DR: Identification of improved IL28B SNPs and haplotypes for prediction of drug response in treatment of hepatitis $C$ using massively parallel sequencing in a crosssectional European cohort. Genome Med 2011, 3:57.

53. Halfon $P$, Bourliere M, Ouzan D, Maor $Y$, Renou C, Wartelle C, Penaranda G, Tran A, Botta D, Oules V, Castellani P, Portal I, Argiro L, Dessein A: A single IL28B genotype SNP rs12979860 determination predicts treatment response in patients with chronic hepatitis C Genotype 1 virus. European journal of gastroenterology \& hepatology 2011, 23:931-935.

54. Lyoo K, Song MJ, Hur W, Choi JE, Hong SW, Kim CW, Bae SH, Choi JY, Choi SW, Shin EC, Yoon SK: Polymorphism near the IL28B gene in Korean hepatitis $C$ virus-infected patients treated with peg-interferon plus ribavirin. Journal of clinical virology 2011, 52:363-366.

55. De Nicola S, Aghemo A, Grazia Rumi M, Galmozzi E, Valenti L, Soffredini R, De Francesco R, Prati GM, D'Ambrosio R, Cheroni C, Donato MF, Colombo M: Interleukin $28 \mathrm{~B}$ polymorphism predicts pegylated interferon plus ribavirin treatment outcome in chronic hepatitis C genotype 4. Hepatology 2012.

56. Asselah T, De Muynck S, Broet P, Masliah-Planchon J, Blanluet M, Bieche I, Lapalus M, Martinot-Peignoux M, Lada O, Estrabaud E, Zhang Q, El Ray A, Vidaud D, Ripault MP, Boyer N, Bedossa P, Valla D, Vidaud M, Marcellin P: IL28B polymorphism is associated with treatment response in patients with genotype 4 chronic hepatitis C. Journal of hepatology 2012, 56:527-532. 
57. Chevaliez S, Hezode C, Soulier A, Costes B, Bouvier-Alias M, Rouanet S, Foucher J, Bronowicki JP, Tran A, Rosa I, Mathurin P, Alric L, Leroy V, Couzigou P, Mallat A, Charaf-Eddine M, Babany G, Pawlotsky JM: High-dose pegylated interferon-alpha and ribavirin in nonresponder hepatitis $C$ patients and relationship with IL-28B genotype (SYREN trial). Gastroenterology 2011, 141:119-127.

58. Huang CF, Huang JF, Yang JF, Hsieh MY, Lin ZY, Chen SC, Wang LY, Juo SH, Chen KC, Chuang WL, Kuo HT, Dai CY, Yu ML: Interleukin-28B genetic variants in identification of hepatitis $C$ virus genotype 1 patients responding to 24 weeks peginterferon/ribavirin. Journal of hepatology 2012, 56:34-40.

59. Howell CD, Gorden A, Ryan KA, Thompson AJ, Ibrahim C, Fried M, Afdhal NH, McHutchison JG, Shianna KV, Goldstein DB, Shuldiner AR, Mitchell BD: Single nucleotide polymorphism upstream of interleukin 28B associated with phase 1 and phase 2 of early viral kinetics in patients infected with HCV genotype 1. Journal of hepatology 2012, 56:557-563.

60. Miyaaki H, Ichikawa T, Yatsuhashi H, Taura N, Miuma S, Usui T, Mori S, Kamihira S, Tanaka Y, Mizokami M, Nakao K: Suppressor of cytokine signal 3 and IL28 genetic variation predict the viral response to peginterferon and ribavirin. Hepatology research 2011, 41:1216-1222.

61. Lange CM, Kutalik Z, Morikawa K, Bibert S, Cerny A, Dollenmaier G, Dufour JF, Gerlach TJ, Heim MH, Malinverni R, Müllhaupt B, Negro F, Moradpour D, Bochud PY: Serum ferritin levels are associated with a distinct phenotype of chronic hepatitis $C$ poorly responding to pegylated interferon-alpha and ribavirin therapy. Hepatology 2012, 55:1038-1047.

62. Cavalcante LN, Abe-Sandes K, Angelo AL, Machado TM, Lemaire DC, Mendes CM, Pinho JR, Malta F, Lyra LG, Lyra AC: IL28B polymorphisms are markers of therapy response and are influenced by genetic ancestry in chronic hepatitis $C$ patients from an admixed population. Liver international 2012, 32:476-486.

63. Payer BA, Reiberger T, Aberle J, Ferenci P, Holzmann H, Rieger A, PeckRadosavljevic M: IL28B and interferon-gamma inducible protein 10 for prediction of rapid virologic response and sustained virologic response in HIV-HCV-coinfected patients. European journal of clinical investigation 2012, 42:599-606.

64. Miyamura T, Kanda T, Nakamoto S, Wu S, Fujiwara K, Imazeki F, Yokosuka O: Hepatic STAT1-nuclear translocation and interleukin 28B polymorphisms predict treatment outcomes in hepatitis $C$ virus genotype 1-infected patients. PloS one 2011, 6:e28617.

65. Di Marco V, Bronte F, Calvaruso V, Capra M, Borsellino Z, Maggio A, Renda MC, Pitrolo L, Lo Pinto MC, Rizzo M, Fiorenza F, Gerardi C, Grimaudo S, Di Cristina A, Levrero M, Craxì A: IL28B polymorphisms influence stage of fibrosis and spontaneous or interferon-induced viral clearance in thalassemia patients with hepatitis $C$ virus infection. Haematologica 2012, 97:679-686.

66. Takita M, Hagiwara S, Arizumi T, Hayaishi S, Ueda T, Kitai S, Yada N, Inoue T, Minami $Y$, Chung $H$, Ueshima K, Sakurai T, Kudo M: Association of interleukin-28B and hepatitis $C$ genotype 1 with a high viral load and response to pegylated interferon plus ribavirin therapy. Digestion 2011, 84:56-61.

67. Fischer J, Bohm S, Scholz M, Muller T, Witt H, George J, Sarrazin C, Susser S, Schott E, Suppiah V, Booth DR, Stewart GJ, van Bömmel F, Brodzinski A, Fülöp B, Migaud P, Berg T: Combined effects of different interleukin-28B gene variants on the outcome of dual combination therapy in chronic hepatitis C virus type 1 infection. Hepatology 2012, 55:1700-1710.

68. Liu CH, Liang CC, Liu CJ, Tseng TC, Lin CL, Yang SS, Su TH, Hsu SJ, Lin JW, Chen $\mathrm{JH}$, Chen PJ, Chen DS, Kao JH: Interleukin 28B genetic polymorphisms and viral factors help identify HCV genotype- 1 patients who benefit from 24-week pegylated interferon plus ribavirin therapy. Antiviral therapy 2012, 17:477-484.

69. Younossi ZM, Birerdinc A, Estep M, Stepanova M, Afendy A, Baranova A: The impact of IL28B genotype on the gene expression profile of patients with chronic hepatitis $C$ treated with pegylated interferon alpha and ribavirin. Journal of translational medicine 2012, 10:25.

70. Vidal-Castineira JR, Lopez-Vazquez A, Alonso-Arias R, Moro-Garcia MA, Martinez-Camblor P, Melon S, Prieto J, Lopez-Rodriguez R, Sanz-Cameno P, Rodrigo L, Pérez-López R, Pérez-Álvarez R, López-Larrea C: A predictive model of treatment outcome in patients with chronic HCV infection using IL28B and PD-1 genotyping. Journal of hepatology 2012, 56:1230-1238.

71. Sporea I, Popescu A, Curescu M, Sirli R, Dan I, Goldis A, Gradinaru O, Ardelean M, Danila M, Bota S, Deleanu A: The Correlation of II28B Genotype With Sustained Virologic Response In Romanian patients With Chronic Hepatitis C. Hepatitis monthly 2011, 11:975-979.

72. Miyase S, Haraoka K, Ouchida Y, Morishita Y, Fujiyama S: Randomized trial of peginterferon alpha-2a plus ribavirin versus peginterferon alpha- $2 \mathrm{~b}$ plus ribavirin for chronic hepatitis $C$ in Japanese patients. Journal of gastroenterology 2012, 47:1014-1021.

73. Li W, Zeng Y, Wang J, Zhou B, Zhang J, Zhang H, Li J, Wu Y, Hamoudi R, Zhou $Y$ : Predicting sustained viral response to hepatitis $C$ using a rapid and simple IL28B rs8099917 genotyping assay. Antiviral research 2012, 94:54-56.

74. Inokuchi M, Ito T, Nozawa H, Miyashita M, Morikawa K, Uchikoshi M, Shimozuma Y, Arai J, Shimazaki T, Hiroishi K, Imawari M: Lymphotropic hepatitis $C$ virus has an interferon-resistant phenotype. J Viral Hepat 2012, 19:254-262.

75. Kobayashi M, Suzuki F, Akuta N, Sezaki H, Suzuki Y, Hosaka T, Kawamura Y, Saitoh S, Arase Y, Ikeda K, Chayama K, Miyakawa Y, Kumada H: Association of two polymorphisms of the IL28B gene with viral factors and treatment response in 1,518 patients infected with hepatitis $C$ virus. Journal of gastroenterology 2012, 47:596-605.

76. Kim SR, El-Shamy A, Imoto S, Kim KI, Ide YH, Deng L, Shoji I, Tanaka Y, Hasegawa $Y$, Ota M, Hotta H: Prediction of response to pegylated interferon/ribavirin combination therapy for chronic hepatitis $C$ genotype $1 \mathrm{~b}$ and high viral load. Journal of gastroenterology 2012, 47:1143-1151.

77. Petta S, Ferraro D, Camma C, Cabibi D, Di Cristina A, Di Marco V, Di Stefano R, Grimaudo S, Mazzola A, Levrero M, Scazzone C, Craxì A: Vitamin $D$ levels and IL28B polymorphisms are related to rapid virological response to standard of care in genotype 1 chronic hepatitis C. Antiviral therapy 2012, 17:823-831.

78. Tajir M, Elmachad M, Kabbaj N, Laarabi FZ, Barkat A, Amrani N, Sefiani A: Frequency of IL28B rs12979860 single-nucleotide polymorphism alleles in newborn infants and in patients with chronic hepatitis $C$ in Morocco. Genetic testing and molecular biomarkers 2012, 16:981-983.

79. Valenti L, Aghemo A, Stattermayer AF, Maggioni P, De Nicola S, Motta BM, Rumi MG, Dongiovanni P, Ferenci P, Colombo M, Fargion S: Implications of PNPLA3 polymorphism in chronic hepatitis $C$ patients receiving peginterferon plus ribavirin. Aliment Pharmacol Ther 2012, 35:1434-1442.

80. Saito $H$, Ito K, Sugiyama M, Matsui T, Aoki Y, Imamura M, Murata K, Masaki N, Nomura H, Adachi H, Hige S, Enomoto N, Sakamoto N, Kurosaki M, Mizokami M, Watanabe S: Factors responsible for the discrepancy between IL28B polymorphism prediction and the viral response to peginterferon plus ribavirin therapy in Japanese chronic hepatitis C patients. Hepatology research 2012, 42:958-96.

81. Karchava M, Sharvadze L, Chkhartishvili N, Nelson K, Gochitashivli N, Gatserelia L, Dvali N, Dolmazashvili E, Dzigua L, Badridze N, Zhamutashvili M, Tsertsvadze T: IL28B favorable genotype and ultrarapid viral response as the earliest treatment predictors of a sustained viral response in a Georgian cohort infected with the hepatitis C genotype 1 . European journal of gastroenterology \& hepatology 2012, 24:817-823.

82. Ogawa E, Furusyo N, Murata M, Ikezaki H, Ihara T, Hayashi T, Toyoda K, Taniai H, Okada K, Kainuma M, Hayashi J: Insulin resistance undermines the advantages of IL28B polymorphism in the pegylated interferon alpha- $2 \mathrm{~b}$ and ribavirin treatment of chronic hepatitis $\mathrm{C}$ patients with genotype 1. Journal of hepatology 2012, 57:534-540.

83. Tolmane I, Rozentale B, Keiss J, Ivancenko L, Subnikova N, Reinholde Z, Kozlovska I, Sumlaninova N, Laivacuma S, Simanis R: Interleukin 28B gene polymorphism and association with chronic hepatitis $C$ therapy results in Latvia. Hepatitis research and treatment 2012, 2012:324090.

84. Christensen PB, Krarup HB, Laursen AL, Madsen PH, Pedersen C Schlichting P, Orholm M, Ring-Larsen H, Bukh J, Krogsgaard K: Negative HCV-RNA 2 weeks after initiation of treatment predicts sustained virological response to pegylated interferon alfa-2a and ribavirin in patients with chronic hepatitis C. Scandinavian journal of gastroenterology 2012, 8-9:1115-1119.

85. Mira JA, Rivero A, de Los Santos-Gil I, Lopez-Cortes LF, Giron-Gonzalez JA, Marquez M, Merino D, Del Mar Viloria M, Tellez F, Rios-Villegas MJ, Omar M, 
Rivero-Juárez A, Macías J, Pineda JA: Hepatitis C virus genotype 4 responds better to pegylated interferon with ribavirin than genotype 1 in HIV-infected patients. AIDS 2012, 26:1721-1724.

86. Amanzada A, Schneider S, Moriconi F, Lindhorst A, Suermann T, van Thiel DH, Mihm S, Ramadori G: Early anemia and rapid virological response improve the predictive efficiency of IL28B-genotype for treatment outcome to antiviral combination therapy in patients infected with chronic HCV genotype 1. Journal of medical virology 2012, 84:1208-1216.

87. Guo X, Zhao Z, Xie J, Cai Q, Zhang X, Peng L, Gao Z: Prediction of response to pegylated-interferon-alpha and ribavirin therapy in Chinese patients infected with different hepatitis $\mathrm{C}$ virus genotype. Virology journal 2012, 9:123.

88. Dring MM, Morrison MH, McSharry BP, Guinan K, Hagan R, O'Farrelly C, Gardiner CM: Innate immune genes synergize to predict increased risk of chronic disease in hepatitis C virus infection. Proc Natl Acad Sci USA 2011, 108:5736-5741.

89. Knapp S, Warshow U, Ho KM, Hegazy D, Little AM, Fowell A, Alexander G Thursz M, Cramp M, Khakoo SI: A polymorphism in IL28B distinguishes exposed, uninfected individuals from spontaneous resolvers of HCV infection. Gastroenterology 2011, 141:320-325, 325 e321-322.

90. Renda MC, Ruggeri RF, Piazza A, Fecarotta E, Renda D, Pantalone GR, Madonia S, Cottone M, Maggio A: Marked impact of IL28B genotype in the natural clearance of hepatitis $C$ virus in patients with haemoglobinopathies. British journal of haematology 2011, 154:659-661.

91. Nattermann J, Timm J, Nischalke HD, Olbrich A, Michalk M, Tillmann HL, Berg T, Wedemeyer H, Tenckhoff H, Wiese M, Kullig U, Göbel U, Capka E, Schiefke I, Güthof W, Grüngreiff K, König I, Roggendorf M, Sauerbruch T, Spengler $\mathrm{U}$ : The predictive value of IL28B gene polymorphism for spontaneous clearance in a single source outbreak cohort is limited in patients carrying the CCR5Delta32 mutation. Journal of hepatology 2011, 55:1201-1206

92. Suppiah V, Gaudieri S, Armstrong NJ, O'Connor KS, Berg T, Weltman M, Abate ML, Spengler U, Bassendine M, Dore GJ, et al: IL28B, HLA-C, and KIR variants additively predict response to therapy in chronic hepatitis $C$ virus infection in a European Cohort: a cross-sectional study. PLoS Med 2011, 8:e1001092.

93. Mangia A, Santoro R, Sarli R, Mottola L, Piazzolla V, Petruzzellis D, Bacca D, Clemente R, Copetti M, di Mauro L, Lotti G, Sacco M, Stefano I: IL28B CCgenotype association with HLA-DQB1*0301 allele increases the prediction of spontaneous HCV RNA clearance in thalassaemic HCVinfected patients. Antiviral therapy 2011, 16:1309-1316.

94. Rao HY, Sun DG, Jiang D, Yang RF, Guo F, Wang JH, Liu F, Zhang HY, Zhang HH, Du SC, Jin Q, Qin H, Lok AS, Wei L: IL28B genetic variants and gender are associated with spontaneous clearance of hepatitis $\mathrm{C}$ virus infection. J Viral Hepat 2012, 19:173-181.

95. Sterne JA, Sutton AJ, loannidis JP, Terrin N, Jones DR, Lau J, Carpenter J, Rucker G, Harbord RM, Schmid CH, Tetzlaff J, Deeks JJ, Peters J, Macaskill P, Schwarzer G, Duval S, Altman DG, Moher D, Higgins JP: Recommendations for examining and interpreting funnel plot asymmetry in meta-analyses of randomised controlled trials. BMJ 2011, 343:d4002.

96. Schreiber J, Moreno C, Garcia BG, Louvet A, Trepo E, Henrion J, Thabut D, Mathurin P, Deltenre P: Meta-analysis: the impact of IL28B polymorphisms on rapid and sustained virological response in HCV-2 and -3 patients. Aliment Pharmacol Ther 2012, 36:353-362.

97. Shi KQ, Liu WY, Lin XF, Fan YC, Chen YP, Zheng MH: Interleukin-28B polymorphisms on the SVR in the treatment of naive chronic hepatitis $C$ with pegylated interferon-alpha plus ribavirin: A meta-analysis. Gene 2012, 507:27-35.

98. Romero-Gomez M, Eslam M, Ruiz A, Maraver M: Genes and hepatitis C: susceptibility, fibrosis progression and response to treatment. Liver international 2011, 31:443-460.

99. Li S, Hu P, Zhang QQ, Liu YH, Hu HD, Zhang DZ, Ren H: Single nucleotide polymorphisms of the IL28B and sustained virologic response of patients with chronic hepatitis C to PEG-interferon/ribavirin therapy: A meta-analysis: Meta-analysis of IL28B. Hepatitis monthly 2011, 11:163-172.

100. Chen Y, Xu HX, Wang L, Liu XX, Mahato RI, Zhao YR: Meta-analysis: IL28B polymorphisms predict sustained viral response in HCV patients treated with pegylated interferon-alpha and ribavirin. Aliment Pharmacol Ther 2012, 36:91-103.
101. Clark PJ, Thompson AJ, McHutchison JG: IL28B genomic-based treatment paradigms for patients with chronic hepatitis $\mathrm{C}$ infection: the future of personalized HCV therapies. Am J Gastroenterol 2010, 106:38-45.

102. Darling JM, Aerssens J, Fanning G, McHutchison JG, Goldstein DB, Thompson AJ, Shianna KV, Afdhal NH, Hudson ML, Howell CD, Talloen W, Bollekens J, De Wit M, Scholliers A, Fried MW: Quantitation of pretreatment serum interferon-gamma-inducible protein-10 improves the predictive value of an IL28B gene polymorphism for hepatitis C treatment response. Hepatology 2011, 53:14-22.

103. Thomas DL, Thio CL, Martin MP, Qi Y, Ge D, O'Huigin C, Kidd J, Kidd K, Khakoo SI, Alexander G, Goedert JJ, Kirk GD, Donfield SM, Rosen HR, Tobler LH, Busch MP, McHutchison JG, Goldstein DB, Carrington M: Genetic variation in IL28B and spontaneous clearance of hepatitis C virus. Nature 2009, 461:798-801.

104. Medrano J, Neukam K, Rallon N, Rivero A, Resino S, Naggie S, Caruz A, Calvino A, Macias J, Benito JM, Sánchez-Piedra C, Vispo E, Barreiro P, McHutchison J, Pineda JA, Soriano V: Modeling the probability of sustained virological response to therapy with pegylated interferon plus ribavirin in patients coinfected with hepatitis C virus and HIV. Clin Infect Dis 2010, 51:1209-1216.

105. Akuta N, Suzuki F, Hirakawa M, Kawamura Y, Yatsuji H, Sezaki H, Suzuki Y, Hosaka T, Kobayashi M, Saitoh S, Arase Y, Ikeda K, Chayama K, Nakamura Y, Kumada $\mathrm{H}$ : Amino acid substitution in hepatitis $\mathrm{C}$ virus core region and genetic variation near the interleukin $28 \mathrm{~B}$ gene predict viral response to telaprevir with peginterferon and ribavirin. Hepatology 2010, 52:421-429.

106. Akuta N, Suzuki F, Hirakawa M, Kawamura Y, Yatsuji H, Sezaki H, Suzuki Y, Hosaka T, Kobayashi M, Saitoh S, Arase Y, Ikeda K, Chayama K, Nakamura Y, Kumada H: Amino acid substitution in HCV core region and genetic variation near the IL28B gene affect viral dynamics during telaprevir, peginterferon and ribavirin treatment. Intervirology 2012, 55:417-425.

107. Chayama K, Hayes CN, Abe H, Miki D, Ochi H, Karino Y, Toyota J, Nakamura Y, Kamatani N, Sezaki H, Kobayashi M, Akuta N, Suzuki F, Kumada H: IL28B but not ITPA polymorphism is predictive of response to pegylated interferon, ribavirin, and telaprevir triple therapy in patients with genotype 1 hepatitis C. J Infect Dis 2011, 204:84-93.

108. Aghemo A, Degasperi E, Colombo M: Directly acting antivirals for the treatment of chronic hepatitis C: Unresolved topics from registration trials. Digestive and liver disease 2012.

109. Hsu CS, Kao JH: Boceprevir for chronic HCV genotype 1 infection. N Engl J Med 2011, 365:176-177, author reply 177-178,

110. Sherman KE, Flamm SL, Afdhal NH, Nelson DR, Sulkowski MS, Everson GT, Fried MW, Adler M, Reesink HW, Martin M, et al: Response-guided telaprevir combination treatment for hepatitis $C$ virus infection. N Engl J Med 2011, 365:1014-1024

\section{Pre-publication history}

The pre-publication history for this paper can be accessed here: http://www.biomedcentral.com/1741-7015/11/6/prepub

\section{doi:10.1186/1741-7015-11-6}

Cite this article as: Jiménez-Sousa et al:: Meta-analysis: implications of interleukin-28B polymorphisms in spontaneous and treatment-related clearance for patients with hepatitis C. BMC Medicine 2013 11:6.

\section{Submit your next manuscript to BioMed Central and take full advantage of:}

- Convenient online submission

- Thorough peer review

- No space constraints or color figure charges

- Immediate publication on acceptance

- Inclusion in PubMed, CAS, Scopus and Google Scholar

- Research which is freely available for redistribution

Submit your manuscript at www.biomedcentral.com/submit 